IZA DP No. 7710

Women Labor Market Participation in Europe:

Novel Evidence on Trends and Shaping Factors

Angela Cipollone

Eleonora Patacchini

Giovanna Vallanti

October 2013 


\title{
Women Labor Market Participation in Europe: Novel Evidence on Trends and Shaping Factors
}

\author{
Angela Cipollone \\ LUISS University \\ and CeLEG
}

Eleonora Patacchini

Sapienza University of Rome, EIEF, CEPR and IZA

\section{Giovanna Vallanti \\ LUISS University, \\ LLEE and CeLEG}

\section{Discussion Paper No. 7710 \\ October 2013}

\author{
IZA \\ P.O. Box 7240 \\ 53072 Bonn \\ Germany \\ Phone: +49-228-3894-0 \\ Fax: +49-228-3894-180 \\ E-mail: iza@iza.org
}

\begin{abstract}
Any opinions expressed here are those of the author(s) and not those of IZA. Research published in this series may include views on policy, but the institute itself takes no institutional policy positions. The IZA research network is committed to the IZA Guiding Principles of Research Integrity.

The Institute for the Study of Labor (IZA) in Bonn is a local and virtual international research center and a place of communication between science, politics and business. IZA is an independent nonprofit organization supported by Deutsche Post Foundation. The center is associated with the University of Bonn and offers a stimulating research environment through its international network, workshops and conferences, data service, project support, research visits and doctoral program. IZA engages in (i) original and internationally competitive research in all fields of labor economics, (ii) development of policy concepts, and (iii) dissemination of research results and concepts to the interested public.
\end{abstract}

IZA Discussion Papers often represent preliminary work and are circulated to encourage discussion. Citation of such a paper should account for its provisional character. A revised version may be available directly from the author. 
IZA Discussion Paper No. 7710

October 2013

\section{ABSTRACT}

\section{Women Labor Market Participation in Europe: Novel Evidence on Trends and Shaping Factors}

We investigate the changes in women's participation patterns across $15 \mathrm{EU}$ countries over the last 20 years using individual data from ECHP and EUSILC databases. Our findings reveal a role of social policies and institutional factors that is stronger than what has so far been assessed. Labor market reforms explain almost $25 \%$ of the actual increase in labor force participation for young women, and more than $30 \%$ for highly educated women. The effects of labor market reforms on the participation of low skilled women in the labor force are instead surprisingly small. We also find that reforms of the institutional framework towards a model of flexicure labor market are effective in enhancing women labor supply only when deregulation is accompanied by sufficient social compensation.

JEL Classification: J11, J21, J2

Keywords: employment gender gap, labor market institutions, child-rearing, elderly care, flexicurity

Corresponding author:

Giovanna Vallanti

Università LUISS "Guido Carli"

Department of Economics and Finance

Viale Romania 32

00197 Rome

Italy

E-mail: gvallanti@luiss.it 


\section{Introduction}

The importance given to the protection of Human Rights and fundamental freedoms in the European Community Treaties has changed considerably since the European venture was first launched. Since 1975 a series of directives have broadened the principle of equality between men and women to cover working conditions, training and promotion, social security, access to goods and services, maternity protection and parental leave. In 1997 the Amsterdam Treaty enabled the gender dimension to be integrated into all Community policies and established the principle of equal treatment as a fundamental right. Since then, the Member States have introduced different policies and activities fighting gender inequalities. ${ }^{1}$

As a matter of fact, the female participation rate in Europe has increased from around $55 \%$ in the early 90 s to more than $66 \%$ in 2008. In the same period women's employment rate has moved to the same direction, by increasing from $49 \%$ to $61 \%$. This steady improvement in women labor market position has led to a significant decline in the gender employment gap, which has nearly halved since 1990 , from more than $25 \%$ to almost $14 \%$ in $2008 .^{2}$

The extent to which reforms and labor market institutions have contributed to such a pattern is at the forefront of the political debate. Although there is a variety of studies looking at this issue from different perspectives, the available evidence is still inconclusive (see Costa, 2000 and Del Boca and Locatelli, 2006 for recent reviews). The main difficulty is disentangling the effect of interest from other (concurrent) factors that drive such patterns, such as: a) changes in cultural attitudes towards work especially in countries where participation is traditionally lower ${ }^{3}$; b) changes in the characteristics of the female population such as fertility decisions and elderly care responsibilities ${ }^{4}$ educational choices ${ }^{5}$ and demographic changes ${ }^{6}$; and c) reforms of the welfare state and changes of labor market institutions and policies specifically targeted at groups with lower attachment to the labor market such as family-related subsidies ${ }^{7}$ and fiscal reductions ${ }^{8}$.

Most of the studies looking at the evolution of the employment (or wage) gender gap over time using individual data focus on a single country only, thus failing to capture important differences across European countries characterized by different welfare structures and cultural attitudes to-

\footnotetext{
${ }^{1}$ In 1997, the Member States of the European Union (EU) unanimously decided to add a new article to the Amsterdam Treaty (Article 13). The new article enabled the Council to take appropriate actions to combat discrimination based on sex, racial or ethnic origin, religion or belief, disability, age or sexual orientation.

${ }^{2}$ This information is retrieved from the OECD labour market statistics, http://stats.oecd.org/.

${ }^{3}$ Algan and Cahuc (2007), Fernandez (2007), Fortin (2005) and Giavazzi et al. (2009).

${ }^{4}$ Goodpaster (2010), Leigh (2010) and Munasinghe et al. (2008).

${ }^{5}$ Ermisch (2003), Euwals et al. (2011), Goldin (2006) and Gustaffsson and Kenjoh (2008).

${ }^{6}$ Beaudry and Lemieux (1999), Fitzenberger et al. (2004) and Balleer et al. (2009).

${ }^{7}$ Anderson and Levine (1999), Attanasio, et al. (2008), Bardasi and Gornick (2003), Berlinski and Galiani (2007), Jaumotte (2003), Powell (1998) Sánchez-Mangas and Sánchez-Marcos, (2008).

${ }^{8}$ Eissa and Liebman (1996) and Alesina and Ichino (2007).
} 
wards female labor market participation. Conversely, cross country comparisons using aggregate data typically fail to distinguish compositional effects (i.e. those arising from changes in the sociodemographic characteristics of men and women over time) and to capture the responsiveness of women with different individual characteristics to changes of the institutional settings (Jaumotte, 2003; Genre et al., 2010).

This paper investigates the changes in women's participation patterns across $15 \mathrm{EU}$ countries over the last 20 years using individual data from ECHP and EUSILC databases. Two are the main contributions of our approach. First, we use individual data for an unusually large set of countries and for a long time period (twenty years). Second, we provide a quantification of the role of labor market institutional factors which is more precise than in previous studies.

Our analysis unfolds as follows.

We begin with an exploratory analysis of the data where individual information is used to compute aggregate trends. Our aim here is to present a picture of each European country where we are able to disentangle how much of the observed decline in the gender employment and participation gaps can be simply attributed to changes in demographic and social characteristics between men and females over time and how much of it needs to be attributed to changes in the institutional setting and cultural attitudes. Our findings reveal that a significant part of the catching up of women labor market performance can be attributed to forces which are not related to the increased similarity between women and men in terms of socio-demographic factors such as for example education.

Next, we use a regression analysis to understand whether the impact of individual characteristics on labor market participation varies across time and across countries in different welfare regimes. Our estimates reveal that the observed aggregate increase in female participation in Europe hides substantial differences in several dimensions, not only across different groups of women and across countries but also for the same group of women in different countries. Our findings thus uncover an important (and under-explored) cross-country heterogeneity in the factors which affect women labor market outcomes.

Finally, we further these results by exploiting a multi-level model specification to appreciate how institutional and policy factors affect women's choices between unpaid family responsibility (child rearing and elderly care) and paid occupation. In particular, our multi-level regressions allow (1) to disentangle how much of the observed variation in the female participation rate occurred in Europe since the beginning of 90 s is due to unobserved (individual and country) heterogeneity versus observed labour market institutional and policy changes and (2) to assess whether such changes have affected differently the participation of women with different characteristics. Although those issues are at the forefront of the political debate, the existing empirical evidence is extremely 
scarce. Differently from previous studies, which essentially capture the interplay between micro and macro characteristics using interaction terms in (single-level) regression models, ${ }^{9}$ our approach can better handle the hierarchical structure of the data (as we observe women nested in countries), thus delivering more accurate estimates of any macro-effects.

Our findings point towards a strict interplay between the individual characteristics of female population and the institutional and policy setting, revealing a role of institutional factors that is stronger than what has so far been assessed. According to our results, the attitude to work of young women with children appears to be favoured by policies aimed to support family and by the expansion of flexible forms of employment (especially in terms of fixed term contracts) to the extent that such forms of employment are not perceived to be of low quality. In particular, we quantify the extent to which changes in the labor market behavior of women with specific characteristics (e.g. young children) are to be attributed to changes in policies and institutions. Labor market reforms and changes of social policies predict almost $25 \%$ of the actual increase in labor force participation for young women, and more than $30 \%$ for highly educated women. However, the effects of labor market reforms on the participation of low skilled women in the labor force are surprisingly small. This result is apparently in contrast with the existing empirical evidence which shows that less educated women (with a lower attachment to work) are more responsive to work incentives created by policy/institutional changes (Del Boca et al 2009). Nevertheless, we argue that in many European countries, labour market reforms has led to a deterioration of job quality, especially for low educated women, increasing the risk of dropping out from the labor force. ${ }^{10}$

The paper is organized as follows. In Section 2 we discuss the relevance of the institutional context in shaping women's choices between unpaid family responsibility and paid occupation and define our research questions. Section 3 describes the data and summarizes the large quantity of micro-level information available for different European countries and across time using a synthetic indicators of female labor market performance. Section 4 contains the results of a regression analysis of women's involvement in the labor market across time and countries, whereas Section 5 analyses more closely the role of the labor market institutional framework and social policies. Section 6 concludes.

\footnotetext{
${ }^{9}$ See, among the others, Stier et al. (2001) and Lippe (2001).

${ }^{10}$ Employment in Europe 2001 reports that drop-out rates from employment into unemployment or inactivity are strongly linked to job quality. High levels of involuntary temporary contracts and part-time work are associated with high drop out rates (some 15\% into unemployment and 10\% into inactivity). Del Boca et al (2009) show that the influence of part-time on participation is positive only where part-time jobs are perceived to be of 'high quality'.
} 


\section{Women's family responsibility, paid work and institutions}

A large empirical literature provides evidence that the provision of facilities, parental leaves and subsidies for day-care spaces and, more generally, policies aimed at alleviating the financial burden of child-rearing, have a positive effect on female labor market integration by either increasing work attachment (less women leaving occupation after childbirth) or facilitating women re-entry into the labor market as children grow up (see, e.g., Sànchez-Mangas and Sànchez-Marcos, 2008, Lefebvre et al., 2009).

Differently from child care policies, there is still little evidence on the role of elderly care policies and norms on women's attitude to paid work. ${ }^{11}$ Policies and practices concerning the reconciliation of child care and employment may not be easily transferred to elderly care. First, caring responsibilities for elderly usually occur at a later phase of work career than child care. Second elderly care is less predictable in timing, duration and intensity (Keck and Saraceno, 2009). Theoretically, on the one hand, the presence of monetary subsidies and publicly financed elderly care services may have a positive effect on the choice of remaining in the labor force. On the other hand, unconditional cash transfers for elderly care, when combined with other sources of income, such as the dependent elderly's pension, may create an "incentive trap" by reducing the opportunity cost of informal care, thereby exerting a negative impact on labor market participation of low income and low educated women (Simonazzi, 2009)

Next to fiscal and social policies for the support of working mothers/elderly carers, the role played by more general changes in the institutional context is gaining an increasing attention in the political debate. In the last two decades, the labor markets in many European countries have experienced deep changes towards the promotion of a flexicurity model of labor market with the aim of increasing competitiveness, employment creation and redistribution of work. Though the idea of deregulation was the common factor behind the waves of reforms, the promotion of flexicurity was pursued through very different types of interventions on both the flexibility and security side. In the Social Democratic countries, reforms were mainly aimed to reduce the protection of insiders by reducing the degree of employment protection on regular forms of employment on the one hand, and increasing income security on the other. ${ }^{12}$ In the Southern countries and some Continental countries, flexibility has been obtained through marginal reforms which aimed at deregulating the use of temporary or

\footnotetext{
${ }^{11} \mathrm{With}$ regard to the effect of the presence of an elderly relative on women labour supply, the existing studies have not evidenced a clear relationship. Wolf and Soldo (1994), estimating simultaneously the choice of employment and elderly care cannot find any negative relationship. Ettner (1995) for the US, Heitmueller and Michaud (2006) for the UK and Casado et al. (2007) for Spain show that co-residing with a disabled senior person has a relevant discouraging effect on participation in the labour market. Chang and White-Means (1995) find that co-residing with the senior person has a negative effect on women participation and that such effect is particularly strong for low educated women.

${ }^{12}$ This is the so called Danish model of flexicurity.
} 
"atypical" forms of employment while leaving largely unchanged the legislation applying to the stock of workers employed under permanent (open-ended) contracts. In other countries, as for example in the Netherlands, the emphasis of the reforms was to promote flexible working time and part time arrangements. Such reforms can be regarded as beneficial to women to the extent they facilitate labor market integration. However, this integration may occur at the risk of a reinforcement of the traditional separation of gender roles in the labor market and within the family.

From the flexibility side, the link between labor market deregulation and women participation is not clear-cut, though there are a number of empirical studies which show that the negative effects of strict Employment Protection Legislations (EPL) are disproportionately larger for those individuals (such as prime-age women) who are more subject to labor market entry problems. As a result, in a rigid labor market, employment opportunities for prime age women are significantly reduced because they are more likely than men to move between employment and inactivity due to the competing demands of work and family life (OECD, 2004; Heckman, J. and C. Pages, 2000). From the security side, whether or not the presence of a generous system of unemployment benefit accompanied by active (and activation) policies increases incentives to work largely depends on the eligibility requirements. In many countries, the access to social security and to active labor policies are interdependent and depend on the past work history of workers (for example contribution records showing recent and continuous employment). These requirements may represent a barrier for women who may have interrupted careers and work part time. This implies that, while, on the one hand, the burden of flexibility is increasingly borne by women, on the other, women are more likely to be excluded from benefits and active policies. Thus, if women are in principle supposed to benefit from the combination of flexibility in the labor market and security in the social system, the tendency towards the flexibilization of the labor market may exert a negative impact on the incentives to participate when flexible occupations are of lower quality and poorly securitized.

In this paper, we investigate the role of the welfare regime-specific characteristics in explaining the observed trends in female labor market performance. We model two dimensions of welfare regimes: (1) the social policies in support to families involved in informal care, both child-care and elderly care, and (2) the institutional characteristics of the labor market in terms of the degree of flexibility and security.

More specifically, we test two main hypotheses:

$\mathrm{H}_{1}$ : social policies more oriented to support families with young children (including the maternity, parental and childcare leaves) and dependent elderly persons have a positive impact on women participation, by weakening the trade-off between informal care and paid work and positively affecting women labor market participation; 
$\mathrm{H}_{2}$ : changes in the institutional setting towards a model characterized by lower barriers to hiring and firing combined with a higher social protection (passive labor market policies and active labor market policies) have a positive impact on female labor market activity and this effect is larger for women who are more involved in family (unpaid) occupations.

We will refer to the variables capturing the characteristics of institutional context and policies as "macro" factors.

\section{Data and exploratory evidence}

\subsection{The data}

We combine micro data from two different sources, the ECHP (European Community Household Panel) and the EU-SILC (European Union Statistics on Income and Living Conditions), to create a unique dataset of comparable household and individual level characteristics across countries and over time.

The ECHP micro data is a household survey with a common framework conducted across EU15 Member States under the supervision of Eurostat. The total duration of the ECHP is 8 years, running from 1994 to $2001 .{ }^{13}$ The dataset includes information on family size and composition, living conditions and several income measures. Therefore, it provides a source of mutually comparable information at individual level for the EU member countries at the turn of the twentieth and twentyfirst centuries.

EU-SILC (European Union Statistics on Income and Living Conditions) is the successor of the ECHP. The EU-SILC provides harmonized cross-sectional and longitudinal multidimensional micro data on income and social exclusion in the European countries, and it is the largest comparative survey of European income and living conditions. ${ }^{14}$

In order to obtain a unique dataset of comparable household and individual level characteristics across the EU countries within the whole period 1994-2009, we limited the analysis to the EU-15 Member States. ${ }^{15}$ The overall sample includes 1,657,367 individuals between 25 and 64 years old of which 851,010 women and 806,357 men. A list of the variables used in this study, as well as summary statistics for the women and men samples, are reported in Tables 1 and 2. The employment and participation rates stand at $59 \%$ and $66 \%$, respectively, for the female sample, and increase to

\footnotetext{
${ }^{13}$ ECHP data were first collected in 1994, when a sample of 60,500 nationally representative households (i.e. approximately 130,000 adults aged over 16) were interviewed in 12 member states. Austria has joined the project in the second wave in 1995, Finland in 1996, and Sweden in 1997. Therefore, since then, the data is covering all EU-15 member states.

14 In the 2004 wave, EU-SILC covered all EU-15 member states except Germany, Netherlands and the UK. Since 2005, the dataset involves the 25 EU member states, plus Norway and Iceland. The 2009 wave has been recently released.

${ }^{15}$ Namely, Austria, Belgium, Denmark, Finland, France, Germany, Greece, Ireland, Italy, Luxembourg, Netherlands, Portugal, Spain, Sweden, United Kingdom.
} 
approximately $80 \%$ and $86 \%$, respectively, for the male sample. The percentage of highly educated women and men is $27 \%$ and women are slightly more represented than men among the lowest educated individuals. Over $65 \%$ of respondents in both samples declares to live in-couple. $42 \%$ of women and $23 \%$ of men live in households with at least one child under 14 years old, and $18 \%$ of them live in households with at least one pre-school age child. Co-living with elderly (that is, individuals with 70 years old or more) involves just $6 \%$ of all individuals in our sample. Approximately $27 \%$ of those living in couple, have a partner with a lower or an upper secondary education (ISCED 0-2 and ISCED 3-5); $20 \%$ of individuals have a highly-educated partner (ISCED 5-7). The variable "cycle" measures the business cycle frequencies of national GDP over the survey years, 1994-2009. This variable has been obtained by implementing the filter proposed by Hodrick and Prescott (1997).

\subsection{A micro-data-based cross country comparison}

We begin our analysis by providing some preliminary evidence of the changes in the gender gap for participation and unemployment. Using data feom the OECD labor Force Statistics, Figures 1 and 2 show the evolution of the activity rates and unemployment rates in the different European countries separated by gender. Figure 1 points towards the well-known onset of female labor market participation, especially in countries with a traditionally low attachment of women to the labor market such as Greece, Ireland, Italy and Spain. Interestingly, Figure 2 shows that the unemployment rates do not exhibit similarly marked trends. This evidence thus seem to suggests that the relevant achievements of women in terms of labor market performance are to be attributed to the supply side of the market. In fact, the increase in female activity rate originates from an increase of female employment due to the increased willingness of women to work rather than from a decrease in the unemployment rate. However, the relevant question that these aggregate indicators are not able to answer is how much of these trends can be attributed to forces which are not related to the increased similarity between women and men in terms of socio-demographic factors such as, for example, education. Such changes in outcomes over and above those stemming from natural demographic trends across countries and over time are of particular interest for policy purposes as they might be the consequence of reforms in the institutional setting.

In our analysis, we use micro data to disentangle aggregate trends into different sources.

We start by looking at the extent to which women differ from men along two different labor market indicators (participation and unemployment) in the different European countries, once the influence of demographic and social characteristics has been controlled for. We use the methodology introduced by Vidgor (2008) to measure differences between native and immigrants in US states along cultural and economic lines. Such an approach allow us to summarize the large quantity of micro-level information available for different European countries and across time in a way that eases 
cross-country comparisons. ${ }^{16}$ In words, the procedure predicts which individuals are females on the basis of observed characteristics and then uses this finding to measure the gap between men and females for a chosen outcome, such as the activity rate, by constructing a numeric index. The method requires no prior assumptions regarding which characteristics are most effective in distinguishing women from men. Moreover, the inclusion of irrelevant characteristics - that is, ones that do not actually help to distinguish women from men - has no impact on the index. Such an index ranges between 0 and 1 . It can be interpreted as an index of dissimilarity: the larger is the distance from 1 , the more females are different from men along the inspected labor market indicator, controlling for other individual characteristics. More specifically, we control for differences in demographic factors using individual information on age and the education level as well as in family structure using marital status, partner education and number of children. A value of 1 for the index indicates that, if those characteristics were equal between men and females, women and men would not differ in terms of the chosen labor market outcome. Departing from 1 indicates that there are other forces (other than those stemming from natural demographic trends) which make women's labor market performance worse than the one of men.

We construct two different indices capturing gaps between women and men in labor market participation (activity gap index) and unemployment (gap index for those in the labor force) (see Appendix 1). The activity index captures differences between women and men inside and outside the labor market, thus revealing behavioral differences more likely to come from the supply side of the labor market. The unemployment index focuses on gender differences for the individuals in the labor market only, and hence captures the behavioral differences more likely to come from the demand side.

Figures 3 and 4 show the results. ${ }^{17}$ They reveal important cross-country differences in the determinants of the aggregate trends that were not captured in Figures 1 and 2. It appears that in most of the countries with a significant catching up of women labor market participation (such as the Mediterranean countries, plus Ireland; Figure 1) changes in demographic and social characteristics (i.e. the increasing similarity between women and men in terms of observable individual characteristics) cannot explain all the shrinking in the gap. Indeed, our corresponding micro-based gender gap indices in Figure 3 remain far from 1, although they are increasing towards 1 over time. This evidence suggests that there are other forces which contributed to the observed remarkable increase in women's involvement in the labor market. Similarly, the reduced gender gap in unemployment

\footnotetext{
16 Technical details can be found in Appendix 1.

${ }^{17}$ For each European country and each year between 1994-2000 (ECHP data) and between 2004-2009 (EU-SILC data) we compute the two different indicators and perform T-test statistics to assess significant difference between the beginning and the end of the observed time window. The complete list of results is collected in Appendix 2 Tables A1-A2.
} 
rates in Spain and the Netherlands (Figure 2) are associated with significant movements in our micro-based gender gap indices in Figure 4, indicating a limited role for changes in the female labor force composition. On the other hand, the marked changes in female unemployment in Italy and Finland (Figure 2), seem to be mainly due to demographic trends and other characteristics of the female labor force factors rather than to changes in preferences, beliefs or labour market policies. Indeed, when controlling for these factors, i.e. when looking at the results obtained using our indicators in Figure 4, the changes in the unemployment gap between men and women in those countries are not statistically significant.

We now focus on the information provided by our different indices within the countries in the sample. Interestingly, it appears a picture with a feature that is common to most of the European countries: the marked changes in our micro-based gender gap index in activity rates are associated with a substantial stability of the same index in unemployment rates. This finding reveals that the observed changes in unemployment rates (or employment rates for those participating to the labor force) largely reflect changes in demographic and social factors, whereas other forces seem to shape female participation rates. This evidence thus seem to provide some support to the idea that female participation rates are driven by changes in country specific characteristics, such as institutional reforms and cultural attitudes towards work. As stressed in the introduction, the importance of these factors in influencing labor market performance is receiving a growing attention among economists.

In conclusion, our micro-based gender gap indices in activity and unemployment rates reveal a relevant degree of cross country heterogeneity in the way the increased similarity between women's and men's individual observable characteristics has contributed to the improvement in women's labor market performance. Indeed, while in many countries the gradual decline of the gender differences in the characteristics of the labor force are able to explain most of the observed trends, in countries traditionally characterized by a persistent male breadwinner model the remarkable increase of women's participation in the labor market must be attributed to country-specific changes which affect policies, institutions and cultural attitudes. In Europe, cultural differences across countries are largely reflected in different welfare regimes. The following section looks in detail at the role played by the welfare regimes in shaping women's labor market behavior.

\section{Female labor market outcomes and welfare regimes}

In this section, we evaluate how individual characteristics impact differently the probability of participating the labour market both across time and across welfare regimes. We estimate a standard probit model for female labor supply separately for countries with different welfare regimes and 
then we interact the main determinants of participation with the trend variable in order to detect differences in trends for women with different characteristics.

\subsection{Cross country differences}

Our basic regression model specifies the labor market status as:

$$
y_{i j}^{t}=\delta \mathbf{X}_{i j}^{t}+\gamma a g e_{i j}^{t}+\lambda \text { trend }^{t}+\text { ocycle }_{j}^{t}+c t y_{j}+\varepsilon_{i j}^{t}
$$

where $y$ is the labor market status (active) at time $t$ for individual (female) $i$ in country $j$, age are dummies for the age group of individual $i(25-34 ; 35-44 ; 45-54 ; 55-64)$, cycle is a business cycle indicator (country specific and time variant), trend is a common linear trend, cty are country dummies and $X$ is a set of individual characteristics observed at time $t$. Following the existing empirical literature on women labor market participation, we include controls for the marital status, the level of education, the partner's level of education, and for family burden. In particular, besides the traditional controls for family care involvement such as the presence, age and number of children, we also include a dummy for the presence in the household of an elderly person above the age of 70 as a proxy for elder care burden. As Ettner (1995) points out, although the decision to care for a senior person and the decision of fertility differ in many aspects, the influence of the commitment to caring for the elderly can be studied similarly to the commitment towards children. ${ }^{18}$

In order to investigate the differences in the women labor market attitude across countries with different welfare regimes, we follow the Ferrera's (1996) classification and divide the countries of our sample into four major groups: Southern (Spain, Italy, Greece, Portugal), Social Democratic (Sweden, Finland, Denmark), Liberal (United Kingdom) and Continental (Austria, Belgium, France, Germany, Netherlands, Ireland, Luxemburg). Table 3 presents the estimation results for the whole pooled sample (15 countries) in column 1 and for each welfare regime separately in columns 2-5. ${ }^{19}$

\section{[TABLE 3 AROUND HERE]}

The results in Table 3 show that there are important differences across welfare regimes in the impact of individual characteristics. Being married is negatively related to women participation and employment and the effect is stronger in those countries characterized by more traditional family

\footnotetext{
${ }^{18}$ In some respect, the presence of an elderly relative in the household can be a better proxy of care burdens than having children. This variable is indeed less affected by endogeneity issues that may arise in the estimation as a consequence of the possible inverse causal relationship between labour market status and the rational choice of having a child (Cipollone and D'Ippoliti, 2011).

${ }^{19}$ Not surprisingly, the results for the employment rate are qualitatively the same as those reported for the participation rate, with some differences in the magnitude of the impacts. While activity rates are widely used as an indicator of labour market involvement, it is increasingly recognized that employment and hours worked are the key indicators for assessing women labour market integration (Jonung and Persson, 1993). One reason is that women unemployment is often hidden among those defined as inactive because of the low work attachment of women of specific groups (typically low skilled women with young children). Results are available upon request.
} 
structure such as continental and southern countries. Education is also another important determinant of the female labor market status and, as expected, a high level of education leads to more participation. The level of education of the partner has also a significant impact on female participation. Finally, the age effects show the familiar hump-shaped pattern in both the participation and employment, implying an increase in the probability of participating for the age group 35-44, and then a lower probability for older groups.

Family care burdens are strong negatively related to female labor market involvement regardless the welfare regime, though with some important differences in the magnitude of the coefficients. The presence (and the number) of young children exhibits a negative impact and this effect is significantly stronger if children are below 4 years old. Labor market participation increases gradually when the child starts attending school and the child effect reverses only when she attends secondary school (around 14 years). ${ }^{20}$ The importance of children's age differs across regimes and is the most critical in the UK. In Southern countries, which are characterized by lower participation rates for mothers, the age of the youngest child exerts a less detrimental effect on participation ${ }^{21}$, thought the negative effect persists even when the child is of school age. Indeed, our estimates show that the probability of participating for women with a child older than 14 (relative to women without children) is almost 4 percentage points lower in the South of Europe than in the Social Democratic countries, and 3 percentage lower than in Continental countries and the UK.

As for children, the estimated impact of elderly care responsibilities on participation is negative and significant and depends on the cultural attitude towards elderly relatives. In fact, such an effect is much lower in Southern countries where cohabiting with an elderly relative is a quite diffuse practice and it is not necessarily related to the need of providing care.

Finally, the highest female participation rate is found among those aged in their late thirties/early forties in all the welfare regimes groups we consider and the participation gap between old-aged women (55-64) and younger groups is significantly larger in Southern countries. This is explained both by cultural reasons (older women are of a generation in which low female labor market involvement is expected as part of a male breadwinner system) and by the presence of early retirement

\footnotetext{
${ }^{20}$ Note that the reported coefficients should not be interpreted as causal effects, as both participation and fertility may be simultaneous decisions. This implies that the causal effect of children on participation can be lower than those estimated.

${ }^{21}$ This may be due to a number of factors, such as differences in the composition of the labor force and in the institutional setting. In countries where female labor force participation is low, women in employment are typically characterized by a higher level of education, implying a stronger labor market attachment. Moreover, labor market institutional rigidities in Southern countries - which make more difficult (re)entering the labor market after a period of temporary leave - may stimulate higher continuity in work attachment. This difficulty in re-entering the market seems to be confirmed by the evidence that in the Social Democratic countries (and to a less extent in the Continental countries) mothers' participation and employment increase steadily as the youngest child grows up (mostly through a re-entry to part time employment), in Southern countries the presence of children negatively affects female labor market participation, even when the child is of school age.
} 
pension schemes which favoured an early drop out.

After controlling for personal characteristics and country unobserved time invariant effects, the trend indicator is positive and significant, implying that, on average, the probability of participating is 0.18 percent higher in 2009 than in 1994.

\subsection{Trends}

We then allow the impact of the determinants of female labor behavior to vary over time by estimating the following model where the trend indicator is interacted with the individual characteristics:

$$
\begin{aligned}
y_{i j}^{t}= & \delta \mathbf{X}_{i j}^{t}+\gamma a g e_{i}^{t}+\lambda \text { trend }^{t}+\text { ocycle }_{j}^{t}+ \\
& \omega\left(\text { trend }^{t} \times a g e_{i}^{t}\right)+\chi\left(\text { trend }^{t} \times \mathbf{X}_{i j}^{t}\right)+c t y_{j}+\varepsilon_{i j}^{t}
\end{aligned}
$$

where trend $^{t} \times \mathbf{X}_{i j}^{t}$ captures changes over time in the labor market status of women with certain characteristics. Such a specification answers questions such as: does the participation rate of women with a high level of education change in 2007 with respect to 1994? As before, the equation (2) is estimated on both the whole sample and each welfare regime separately. Table 4 reports the results.

[TABLE 4 AROUND HERE]

Overall, the evidence shows that there are important differences in the trends of women's participation, depending on both the personal and family characteristics of women and on the welfare regimes. While in the UK, the positive trend is quite homogenous across women in different age groups, in Continental and Southern countries, the increase in participation and employment is more evident for older age groups and this is partly explained by cohort effects. ${ }^{22}$ Education (and partner's education) appears to have an increasing role in stimulating women labor market involvement, with some differences across regimes. Indeed, we find a significant increase in the share of high educated women leaving the inactivity status in the Continental and Social Democratic countries, while, in Southern countries, the trend is stronger for women with a low-medium level of education.

Over time, the labour market participation increases for women with small children. Again, such increase is not uniform across welfare regimes. It emerges that, between 1994 and 2009, the negative impact of young children on women labor market involvement declined significantly in Social Democratic countries and to a less extent in Continental and Southern countries, while no trend has been detected for the UK. This phenomenon may be related to a larger availability of market (child

\footnotetext{
${ }^{22}$ In fact, while there is not a substantial difference in the labor market behavior of women in their mid 20 s and 30s (born after the early 1960s and grew up and educated after the feminist movement in the '70s), for those in their mid $30 \mathrm{~s}$ and $40 \mathrm{~s}$, the participation rate has increased by 11 percentage points, and for those older than 45 by almost 20 percentage points.
} 
care services) or non market child care services (i.e., husband's or relative's help) accompanied by a shift in people's values in all European countries (and to a larger extent in the most traditional ones) from the traditional breadwinner arrangements in favour of a more equal gender division of roles within the household. This change in the attitude towards working mothers could also have been favoured by the expansion of flexible forms of employment which facilitates the conciliation between family responsibilities and paid work.

The negative impact of informal elderly care on participation has increased over time (with the exception of Social Democratic countries). According to our results, the presence of a co-living elderly persons has a positive (and significant) impact on female labor market involvement at the beginning of the sample period and then turns to be negative. This seems to be related to the changing role of elderly relatives within the family, from providers of unpaid help within extended family models to recipients of informal long-term care in the nuclear family (Leitner, 2003; Saraceno, 2010; Saraceno and Naldini, 2007).

In summary, the findings in tables 3 and 4 show that the impact of family burden on women labor market participation has changed in the last twenty years and such changes exhibit important country-specific patterns. In the following sections, we further our understanding of the relevance of institutional factors in shaping the women's decisions between unpaid family responsibility and paid work.

\section{The macro policy and institutional indicators}

The previous section provides evidence that trends in female labor market participation differ significantly across countries in different welfare regimes. In this section, we study the role of the labour market institutions and policies in explaining the observed trends by focussing on two dimensions of welfare regimes: (1) the social policies in support to families involved in informal care, both child-care and elderly care - hypothesis 1 in Section 2 -, and, (2) the institutional characteristics of the labor market in terms of the degree of flexibility and security - hypothesis 2 in Section 2 -. Given the multilevel nature of our dataset (women nested in countries), we model female labour supply in a micro-macro design using a multi-level approach. A similar approch has been used by Ward and Dale (1992). ${ }^{23}$

\footnotetext{
${ }^{23}$ Differently from the standard difference-in-difference approach with interaction terms between micro- and macrolevel variables and clustered standard errors, the multilevel method allows the researcher to estimate how much each level of analysis is contributing to explanation in the model, and how much each level is contributing to the error. More specifically, the multilevel method allows one to analyze the explanatory power of a model by estimating the variance components directly and, hence, to state what portion of a dependent variable's variance is attributable to state-level versus individual-level variation generated by both observable and unobservable factors. Moreover, the option of using clustered robust standard errors to account for the intraclass correlation is a "weaker" form of correction than using a multilevel model, which not only accounts for the intraclass correlation, but also corrects the denominator degrees of freedom for the number of clusters. When using clustered robust standard errors, indeed, the denominator degrees of freedom is based on the number of observations, not the number of clusters. Technical details and inferential issues
} 


\subsection{The macro indicators}

We collect several variables related to the country-specific socioeconomic context that are expected to be important in shaping the influence of housework and family related responsibilities on women's attachment to local labor markets. We distinguish six relevant dimensions of cross-countries heterogeneity: the extent of employment protection legislation, passive and active labor market policies, subsidies targeted to elderly people, subsidies targeted to families, and the extent of parental leave. Table 5 presents a description of these dimensions, by reporting on their construction and their specific components.

\section{[TABLE 5 AROUND HERE]}

In order to obtain uncorrelated synthetic indicators from the six macro variables, we employ a Principal-Component Analysis (PCA) separately on the institutions-related dimensions and on the policies-related dimensions. ${ }^{24}$ In keeping with common practice (Nardo et al. (2005), Nicoletti et al. (1999), Kline (1994)), we have selected the first factor of each PCA that satisfies the following requirements: eigenvalues larger than 1 , individual contribution to the explanation of the overall variance larger than $10 \%$, cumulative contribution to the explanation of the overall variance larger than 50\%. Within each factor, dimensions are weighted according to the proportion of the crosscountry variance explained by the factor itself. The results of the two PCA procedures are presented in Table 6 .

\section{[TABLE 6 AROUND HERE]}

The factor of the first PCA (Factor 1, henceforth called POL) is highly correlated with parental leaves and family subsidies (with factor loadings larger than 0.8) and moderately correlated with the extent of subsidies to the elderly (factor loading approximately equal to 0.26 ). The higher the load the more relevant in defining the factor's dimensionality. Hence our first factor reasonably represents the generosity of national welfare regimes to households with dependent children. The factor of the second PCA (Factor 2, henceforth called INST) is defined by active and passive labor market policies (with factor loadings larger than 0.9), while the extent of employment protection legislation exerts an inverse impact on it (with negative factor loading, -0.15). Hence, this factor resumes the degree of flexicurity of national labor market institutions. ${ }^{25}$

\footnotetext{
related to the application of the multilevel analysis techniques can be found in Hox (2010).

${ }^{24}$ Principal-Component Analysis (PCA) aims to convert a set of possibly correlated variables into a lower dimensional set of linearly uncorrelated variables called principal components. These relevant factors are then rotated using the varimax method to maximize the procedure's efficiency (Kline (1994)).

${ }^{25}$ The similarity between the standard definition of flexicurity and our second factor is straightforward. Indeed, the European Commission defines flexicurity as an integrated strategy to simultaneously enhance flexibility and security in the labor market. It is traditionally implemented by means of: 1) flexible and reliable contractual arrangements, which are negatively correlated with employment protection; 2) effective active labor market policies; and 3) modern social security systems providing adequate income support during employment transitions, which are positively correlated with passive labor market policies.
} 


\subsection{The role of policies and institutions}

Our econometric specification consists of a multi-level analysis based on our baseline probit model (1). We allow both the intercept and the impacts of some individual characteristics (namely, having small children and co-living with an old-aged dependent) to depend on the two country- specific (but time variant) macroeconomic factors defined above: INST (labor market institutional context) and POL (family oriented policies).

Our random coefficient model is composed by a first-level regression at individual level specified as follows:

$$
y_{i j}^{t}=\beta_{0 j}^{t}+\beta_{11 j}^{t} C H I L D_{i j}^{t}+\beta_{12 j}^{t} E L D E R L Y_{i j}^{t}+\boldsymbol{\beta}_{2} / \mathbf{x}_{2 i j}^{t}+\varepsilon_{i j}^{t}
$$

and a second level set of regressions as follows:

$$
\begin{aligned}
& \beta_{0 j}^{t}=\delta_{0}+\delta_{1} I N S T_{j}^{t}+\delta_{2} P O L_{j}^{t}+\nu_{j}^{t} \\
& \beta_{11 j}^{t}=\gamma_{10}+\gamma_{11} I N S T_{j}^{t}+\gamma_{12} P O L_{j}^{t}+v_{1 j}^{t} \\
& \beta_{12 j}^{t}=\gamma_{20}+\gamma_{21} I N S T_{j}^{t}+\gamma_{22} P O L_{j}^{t}+v_{2 j}^{t}
\end{aligned}
$$

where $\mathbf{x}_{2}$ is a set of additional controls which capture the impact of others micro-characteristics on the likelihood of women participation.

We implement Generalized Linear Latent Models to estimate a two-level Random-Intercept Probit model and a two-level Random-Coefficient Probit model, taking into account the nesting of individuals in their country of origin. ${ }^{26}$ Differently form the analysis carried on in section 4 we now focus on women in prime age group (25-54) because family care burdens, such as child care and elderly care, are less relevant for those in the elder group (55-64). ${ }^{27}$ The model is estimated for the whole sample (pooled model) and then for each age group separately. We also test whether and to what extent changes in family policies and labor market institutions affect the labor market decisions of women with different levels of education and estimate model (3) for the three education groups (primary, secondary and tertiary education).

The results are reported in Table 7 (column 1 for the whole sample and columns 3-4 for the three age groups separately) and in Table 8 for the three education groups. ${ }^{28}$

[TABLES $7 \& 8$ AROUND HERE]

Both the POL and INST indicators exert a significant impact on women's likelihood of being

\footnotetext{
${ }^{26}$ Cipollone and D'Ippoliti (2011) carried on a similar analysis for Italy, exploiting territorial heterogeneity at regional level.

${ }^{27}$ In particular, the "variable co-living with an elderly relative (older than 70 )" can simply capture the presence of the partner rather then the presence of a relative in need of care.

${ }^{28}$ The estimated coefficients on individual controls are consistent with those reported in the previous sessions and and are available from the authors upon request.
} 
active, though their effect is mediated by the type of unpaid work involvement (presence of child or/and elder person) and differs substantially across age and education groups.

Regarding the role of family policies $(P O L)$, the availability of childcare subsidies and childfriendly policies have a positive impact on the activity rate of women with children and the effect is significant for relative young women (25-34) at the early stage of their work life and, quite surprisingly, for medium and high educated women. Indeed the effect is not significant for low skilled women, whose employment opportunities are limited both in terms of the quality of jobs available and wages. ${ }^{29}$

Conversely, policy measures to help women to combine caring and job responsibilities affect differently the willingness to work of women co-living with an elderly person. The estimated effect is in general negative and significant for older (age group 44-55) and low educated women. These results show that the effect of policies on women's choice between paid work and unpaid care crucially depends on their outside family options and labor market potential outcomes. In general, cash benefits increase household income and rise the reservation wage at which women are available for working. Therefore, more generous supports for child-related and elder-related costs are more likely to discourage the labor market participation of low-skilled women in charge of family care, since their labor market options (in terms of wage and type of jobs) are poorer.

Turning to the effects of the institutions indicator (INST), more flexibility and/or more security is employment-enhancing for young women (25-34) with small children despite the level of education. These results imply that a larger availability of flexicure job opportunities favors the labour market participation of women with children, especially at the beginning of their working career, by reducing the labor market entry costs.

Women with elderly care responsibility respond differently to changes in the labour market institutional framework. Higher labor flexibility is detrimental for the labor market involvement of women co-living with an elderly person. This result may be related to the fact that just few countries in Europe have combined the two dimensions of flexibility and security ${ }^{30}$, and, in most cases, deregulation is moving forward without sufficient social compensation. In this respect, the growing availability of flexible (low-paid jobs), which very often represent a forced alternative rather than an option to more stable forms of employment, makes unpaid elderly caring more attractive than paid occupations, especially in countries where family caring activities are supported by monetary

\footnotetext{
${ }^{29}$ Such results may be related to the fact that the indicator $P O L$ includes both in-kind (maternity and paternity leaves, child care facilities ecc.) and monetary (family allowances) transfers. While the former have a positive impact on mothers labour market attachement, the latter may have a negative impact which is stronger for low-income mothers (Del Boca et al. 2009).

${ }^{30}$ Combining the two axes of flexibility and security, Tangian (2007) concludes that only Denmark and Netherlands are developing both dimensions.
} 
allowances that can be freely used to complement the family budget. ${ }^{31}$ This is confirmed by the fact that the effect holds for low-medium educated women whose work propensity is lower and work opportunities are in general poorer.

To summarize, the institutional characteristics of the labour market and the social policy environment affect significantly women labour market behavior, thought the effect is mediated by the women's individual characteristics. In particular, social policies aimed at those women involved in family care, have a strong a significant impact on the labour market participation of young mothers with a medium-high level of education. The effect is nevertheless negative when older and low skilled women and involved in elderly care. The institutional characteristics of the labor market impact significantly on the participation of mothers at early stage of their working career who benefit more of a larger availability of flexible forms of employment and a reduction of the labour market entry costs. The same result does not hold for low skilled women with elderly care responsibilities.

Our results indicates that social policies and labor market institutional characteristics explain a non-negligible percentage of the women's labour market participation across European countries. The variance partition coefficient (VPC) for the overall model (Table 7, column 1) is approximately equal to 0.06 , which indicates that $6 \%$ of of the variability in the participation rates can be attributed to countries factors. This coefficient increases when the model is separately estimated by agegroup and educational level. In particular, macroeconomic heterogeneity is particularly relevant in explaining cross-country differences in the participation rates of younger and less skilled women (VPC increases up to $20 \%$ and $11 \%$ respectively), while more than $95 \%$ of variability of participation of women between 45 and 55 years old is due to individual characteristiocs. The macro factors INST and $P O L$ explain up to $67 \%$ of the overall cross-countries variance, as shown by the level- 2 variance partition coefficients. Thus there remains some country-level variance unaccounted for in the model. This may be attributed to changes in cultural attitude towards female labor market involvement, as well as other country-specific time-variant factors which have not been explicitly considered in the model.

\subsection{The role of flexicurity}

In the last set of regressions we focus more specifically on the impact of flexicurity on women labor market involvement by disentangling the impact of the two components of the indicator INST: flexibility $(F L E X)$ and security $(S E C)$ and their interaction $(F L E X \times S E C)$.

The results for the pooled sample (column 1) and for the three age groups separately (columns 2-4) are reported in Table 9, while in Table 10 we run the same regressions for women with different levels of education.

\footnotetext{
${ }^{31}$ See Simonazzi (2009) for a detailed analysis of the recent dynamics of the care sector in the EU countries.
} 
[TABLES $9 \& 10$ AROUND HERE]

Table 9 shows that a higher degree of labor flexibility has a positive effect on the activity rate only if it is accompanied by policies which are aimed to guarantee access to employment security in terms of both active labor market policies and the inclusiveness of the unemployment benefits. At the same time, a larger degree of security is beneficial for women's involvement only in sufficiently flexible labor markets which provide an easier access to employment. The impacts of flexibility, security and their interactions are significant and qualitatively the same across age groups with the exception of those in the oldest age group (44-54 in our sample). The interaction between flexibility and security are stronger for young women at the early stage of their working career and, consistently with the results found in the previous set of regressions, for those women with family care responsibilities. These results suggest that combining a high degree of labor market flexibility with a high level of social protection leads to significant gains in terms of women's labor market participation, while omitting one of the two aspects can produce sub-optimal (or even negative) outcomes in terms of labor market performance. The marginal effect of flexibility on female activity rate turns to be positive in correspondence of a value of the security indicator above 2.00 (2.05 for women with young children and 1.92 for women involved in elderly care). On the other hand, the marginal effect of security turns to be positive for value of the flexibility indicator above 1.76 (1.60 and 1.92 for women involved in child and elderly care respectively).

In Figure 5 we can observe that in the period 2004-2009, the countries for which both the flexibility and security indicators are above the estimated thresholds are the Social Democratic countries (though Sweden only marginally), Netherlands and at the margin Belgium, and Germany. ${ }^{32}$ After the institutional reforms implemented in the late nineties and early 2000s to promote a more flexible labor market, Italy appears still deficient on the security side. The opposite holds for France and Spain which are still characterized by a rigid labor market. Greece and Portugal remain well below both the thresholds.

[FIGURE 5 AROUND HERE].

The picture that emerges from this last exercise can be summarized by saying that in the Social Democratic and some central European countries, institutional changes towards the flexicurity model are correlated with positive trends in female labor market participation and this is particular true for young women with kids. On the contrary, in southern European countries and the UK, the security and flexibility mix of workers' jobs is not enough to stimulate women's involvement in labor market.

\footnotetext{
32 Notice that the Social Democratic countries (and to less extent the Continental countries) are also those countries for which we estimated the strongest (negative) trend in the effect of young children on female participation (see table $4)$.
} 


\subsection{Quantifying the influence of institutions and social policies}

We now provide a more precise quantification of the effects of labour market flexibility and security and of the social policies in support to families in shaping women' activity rate. Following the growth accounting methodology proposed by Stoker (1985), it is possible to show that, under plausible restrictions, a first-order difference of our multilevel model provides an Oaxaca-fashion decomposition of changes in women activity rates. Such a decomposition enables us to asses how much of the observed growth in female labor force participation is due to changes in the macro factors (INST and $P O L$ ), as opposed to changes from other sources (such as changes in the individual characteristics). More specifically, the variation of the female activity rate between two periods can be decomposed in five different components. The first term describes how much of the change in women participation rate comes exclusively from changes in individual characteristics, the second term quantifies how much of that change is due to the interplay between - individual characteristics and country-specific unobserved heterogeneity, the third term capture the effects arising from the interaction between changes in individual characteristics and observed macro factors, whereas the fourth component captures the influence of changes in the macro factors INST and POL. The fifth term is a residual component. The technical details of this decomposition are reported in the Appendix 2.

Table 11 collects the estimation results which are obtained using the decomposition for the whole sample, whereas Table 12 shows the evidence for the four welfare regimes separately.

[TABLES 11 \& 12 AROUND HERE]

On average, $6.2 \%$ of the overall increase in female participation between 1994 and 2009 is associated with changes in the institution and policy indicators. Only a small part of the actual rise over time in the proportion employed is associated with the changes in the indicators of institutions and policies in southern countries (around 3\%), while the contribution is remarkable higher in the social democratic countries. For these countries, the INST and POL indicators predict more than $14 \%$ of the actual change in the female participation. This last result is in line with the findings discussed in the previous session, which show that in the social democratic regime, institutional changes towards the flexicurity model are correlated with positive trends in female labor market participation.

Table 13 and Table 14 presents the estimation results for the three age and the three education groups respectively.

\section{[TABLES 11 \& 12 AROUND HERE]}

These results indicate that the contribution of changes of institutions and policies to the growth of female participation is considerably higher when it is calculated for young (24.6\%) women and for high skilled women $(38.6 \%)$. In line with the previous literature, these findings confirm that the social welfare changes and the labor market regulatory reforms in Europe contribute to explain the 
observed trends in the activity rate of women who face higher labour market entry costs, such as young women who are at the beginning of their working career and more involved in child care duties. Interestingly, the mix of labour market reforms and policies changes which have been implemented in Europe in the last 20 years fail to explain the observed pattern of the activity rate of low-educated women.

\section{Conclusions}

In this paper, we provide detailed macro evidence on trends of female labor market participation in the last twenty years for a large set of EU countries using micro data from the ECHP and EU-SILC surveys. Three main results emerge from our analysis.

First, we show that the observed remarkable increase in women's labor market participation between 1994 and 2009 can be explained by significant change in the impact of individual characteristics on women's labor supply. For example, according to our results, the negative impact of childcare on women's participation has declined over time, while informal elderly care has increasingly reduced the likelihood of women to supply labor. Moreover, we find that the observed trends in the labor market participation of women have not been uniform across welfare regimes.

Second, we find that the estimated trends in female labour market participation are related to differences of the labour market institutional setting and of the social policy environment across the countries in the sample. Such policy and institutional factors have an important impact on the labor market opportunities of women by affecting the quality of potential jobs available, the chances to (re-)enter the labor market and the opportunity costs of employment (vs non-employment). However, these effects vary across women with different characteristics, such as the type of family care involvement, the age and the level of education. In particular, the observed positive trend in the attitude to work of women with children appears to be favoured by the expansion of flexible forms of employment (especially in terms of fixed term contracts) which have progressively eased the labor market access and the reconciliation of family child responsibilities with paid work. This positive effect is stronger for women in the early stage of their work life despite the level of education. Generous child and family benefits and maternity/paternity leaves have a positive impact on women labor market attachment of young mothers, and the effect is stronger for medium-high educated individual.

Third, our analysis reveals that the positive trend in female activity rate is related to changes in the institutional framework towards the flexicurity model in countries such as Denmark and Netherlands which are characterized by a balanced mix of flexibility and security. The policy implications of this last set of results are clear: reforms of employment protection towards a larger degree of flex- 
ibility need to be accompanied by an increase in state-provided security. Such a mix of institutional reforms will guarantee, on the one hand, lower entry costs for individuals with a weaker attachment to work and, on the other, a set of incentives to actively participate to the labor market.

Finally, we provide a quantification of how much of the observed trend in women labour market participation can be attributed to changes in the labour market institutional setting and family policies through a simple decomposition exercise. We find that the mix of institutional and policy changes accounts for almost $25 \%$ of the increase of the labour market participation of young women (around 2.5 percentage points) and $38 \%$ of the participation of high educated women (around 1.5 percentage points). Our results also reveal that the changing institutional and policy setting has not favoured the labour market integration of low skilled women in Europe.

\section{References}

[1] Alesina, a., Ichino, a. and Karabarbounis, L. (2007). "Gender Based Taxation and the Division of Family Chores," NBER Working Papers 13638, National Bureau of Economic Research, Inc.

[2] Algan, Y., and P. Cahuc. (2007). "The Roots of Low European Employment: Family Culture?" In NBER International Seminar on Macroeconomics 2005. Eds. C. Pissarides and J. Frenkel, pp. 65-109. Cambridge: MIT Press.

[3] Algan, Y., Bisin, A., Manning A. and T. Verdier (eds) (2012), Cultural Integration of Immigrants in Europe, Oxford: Oxford University Press.

[4] Anderson, P.M. and P.B. Levine (1999). "Child Care and Mothers' Employment Decisions." NBER Working Paper No 7058.

[5] Attanasio. O., Low H. and V. Sanchez-Marcos (2008). "Explaining Changes in Female Labor Supply in a Life-Cycle Model.” American Economic Review 98(4): 1517-52.

[6] Apps, P. and A. Rees (2004). "Fertility, Taxation and Family Policy." Scandinavian Journal of Economics 106(4): 745-63.

[7] Balleer, A., Gomez-Salvador, R. and J. Turunen (2009). "Labor Force Participation in the Euro Area: A Cohort Based Analysis", ECB Working Paper Series No.1049.

[8] Beaudry, P. and Lemieux, T. (1999). "Evolution of the female labor force participation rate in Canada, 1976-994: a cohort analysis", Symposium on Canadian labor Force participation in the 1990s, Special issue of Canadian Economics, vol.7, no.2, pp.57-70

[9] Berlinski, S. and S. Galiani (2007). "The effect of a large expansion of pre-primary school facilities on preschool attendance and maternal employment." Labor Economics 14(3): 665-80. 
[10] Bardasi, E. and J.C. Gornick (2003). "Women and Part-time Employment: workers' choices' and wage penalties in five industrialized countries." in Women in the labor market in changing economies: Demographic issues, eds. Garcia, B., Anker, R. and A. Pinnelli, pp. 209-44. Oxford: Oxford University Press.

[11] Blanchard Olivier \& Augustin Landier, (2002). "The Perverse Effects of Partial labor Market Reform: fixed-Term Contracts in France", Economic Journal, Royal Economic Society, vol. 112(480), pages F214-F244, June.

[12] Casado Marín D., P. García Gómez and A. López Nicolás (2007), Informal Care and labor Force Participation among Middle-Aged Women in Spain, Universitat Pompeu Fabra, Economics Working Papers n. 1023.

[13] Chang, C. and White-Means, S. (1995). "Labor Supply of Informal Care-givers, International Review of Applied Economics, 9(2): 192-205.

[14] Cipollone A. and C. D'Ippoliti (2011). "Women's Employment: Joining Explanations Based on Individual Characteristics and on Contextual Factors," American Journal of Economics and Sociology, Wiley Blackwell, vol. 70(3), pages 756-783, 07.

[15] Del Boca, D., Pasqua, S. and C. Pronzato (2009), "Motherhood and market work decisions in institutional context: a European perspective", Oxford Economic Papers, vol. 61, pp. i147-i171.

[16] Dolado J. J., C. García-Serrano and J. F. Jimeno (2002). "Drawing Lessons from the Boom of Temporary Jobs in Spain", Economic Journal, 112: pp. F270-F295.

[17] Eissa, N. and Liebman, J.B. (1996). "Labor supply response to the Earned Income Tax Credit", The Quarterly Journal of Economics, MIT Press, vol. 111(2), pp. 605-37.

[18] Ermisch J. and Wright R. (1993), "Wage offers and full-time and part-time employment by British women", Journal of Human Resources, vol. 28(1), p. 111-33

[19] Ettner, S.L. (1996). "The opportunity costs of elder care", The Journal of Human Resources, Vol. 31, No. 1, pp. 189-205.

[20] Ettner, S.L. (1995). "The impact of "parent care" on female labor supply decisions". Demography 32:63-80.

[21] Euwals, R., Knoef, M. and D. van Vuuren (2011). "The trend in female labor force participation: what can be expected for the future?", Empirical Economics, vol. 40, pp. 729-753. 
[22] Fernandez, R. (2007). "Women, Work, and Culture." Journal of the European Economic Association 5(2-3): 305-332.

[23] Ferrera, M. (1996) "The "Southern" Model of Welfare in Social Europe", Journal of European Social Policy, vol. 6 (1), pp. 17-37.

[24] Fitzenberger, B., Schnabel, R. and Wunderlich, G. (2004): "The Gender Gap in Labor Market Participation and Employment: A Cohort Analysis for West Germany", Journal of Population Economics 17, pages 83-116.

[25] Genre, V., R. Gomez-Salvador and A. Lamo (2005), "The Determinants of labor Force Participation in the EU" in R. Gómez-Salvador, A. Lamo, B. Petrongolo, M. Ward, and E. Wasmer (eds.) labor Supply and Incentives to Work in Europe, Edward Elgar.

[26] Fortin, N. (2005). "Gender Role Attitudes and Women's Labor Market Outcomes Across OECD Countries." Oxford Review of Economic Policy 21(3): 416-438.

[27] Genre, V., R. Gomez-Salvador and A. Lamo (2010): "European Women: Why Do(n’t) They Work", Applied Economics, vol. 42(12), pp. 1499-1514.

[28] Goodpaster, N.K. (2010). "Leaves and Leaving: The Family and Medical Leave Act and the Decline in Maternal Labor Force Participation.” The B.E. Journal of Economic Analysis \& Policy 10(1): Art. 6.

[29] Gauthier, A.H. (2011). Comparative Family Policy Database, Version 3 [computer file]. Netherlands Interdisciplinary Demographic Institute and Max Planck Institute for Demographic Research (distributors). Retrieved from: www.demogr.mpg.de

[30] Gauthier, A.H. (2011). Comparative Maternity, Parental, and Childcare Leave and Benefits Database (1960-2010) [computer file]. Netherlands Interdisciplinary Demographic Institute and Max Planck Institute for Demographic Research (distributors). Retrieved from: www.demogr.mpg.de

[31] Giavazzi, F., F. Schiantarelli, and M. Serafinelli. (2009). "Culture, Policies and Labor Market Outcomes." NBER Working Paper Series No. 15417.

[32] Guell, M. and B. Petrongolo (2007). "How binding are legal limits? Transitions from temporary to permanent work in Spain," labor Economics, Elsevier, vol. 14(2), pages 153-183, April. 
[33] Gustafsson, S., and E. Kenjoh. (2008). "The Timing of Maternity." In Social Policies, Labor Markets and Motherhood. Eds. D. Del Boca and C. Wetzles, pp. 182-224. Cambridge: Cambridge University Press.

[34] Gustavsson M., 2006. "The evolution of the Swedish wage structure: new evidence for 19922001," Applied Economics Letters, Taylor and Francis Journals, vol. 13(5), pages 279-286.

[35] Heckman, J. and C. Pages (2000), "The Cost of Job Security Regulation: evidence from Latin American labor markets", NBER Working Paper, No. 7773.

[36] Heitmueller, A. (2007). "The Chicken or the Egg? Endogeneity in labor Market Participation of Informal Carers in England", Journal of Health Economics, Elsevier, vol. 26(3), pages 536-559.

[37] Hodrick, R., and E. C. Prescott (1997). "Postwar U.S. Business Cycles: An Empirical Investigation," Journal of Money, Credit, and Banking, 29 (1): 1-16.

[38] Hox, J. J. (2010). Multilevel analysis : techniques and applications - 2nd ed. Routledge: New York and Hove.

[39] Jaumotte, F. (2003). "Female labor force participation. Past trends and main determinants in OECD countries." OECD Economic Studies 37: 52-108.

[40] Johnson, R.W. and A.T. Lo Sasso (2000), "The trade-off between hours of paid employment and time assistance to elderly parents at midlife", mimeo, The Urban Institute, Washington, D.C.

[41] Jonung, C., and I. Persson (1993). "Women and Market Work: the misleading tale of participation rates in international comparisons". Work, Employment and Society 7,2,259-74.

[42] Keck, W. and C. Saraceno (2010). Balancing elderly care and employment in Germany, WZB Discussion Paper, Research Professorship Demographic Development, Social Change, and Social Capital.

[43] Kline, P. (2004), An Easy Guide to Factor Analysis, London, Routledge.

[44] Lefebvre, P., Merrigan, P., Verstaete, M. (2009). "Dynamic labor supply effects of childcare subsidies: Evidence from a Canadian natural experiment on low-fee universal ", labor Economics, Vol.16(5), pp. 490-502

[45] Leigh, A. (2010). "Informal care and labor market participation". Labor Economics 17(1): 14049. 
[46] Lundin, D., Mörk, E. and B. Öckert (2008). "How far can reduced childcare prices push female labor supply?" Labor Economics 15(4): 647-59.

[47] Munasinghe, L., Reif, T. and A. Henriques (2008). "Gender gap in wage returns to job tenure and experience." Labor Economics 15(6): 1296-316.

[48] Nardo, M., Saisana, M., Saltelli, A., Tarantola, S., Hoffman, A., Giovannini, E. (2005), "Handbook on constructing composite indicators: methodology and user guide", OECD Statistics Working Papers, n. 2005/3, Paris.

[49] Nicoletti, G., Scarpetta, S., Boylaud, O. (1999), "Summary Indicators of Product Market Regulation with an Extension to Employment Protection Legislation", OECD Economic Department Working Papers, n. 229, Paris.

[50] Petrongolo, B. (2004). "Gender Segregation in Employment Contracts," Journal of the European Economic Association, MIT Press, vol. 2(2-3), pages 331-345, 04/05.

[51] Powell, L. M. (1998). "Part-time versus full-time work and childcare costs: evidence for married mothers." Applied Economics 30(4): 503-11.

[52] OECD (2004), Chapter 2, Employment outlook, OECD Paris.

[53] OECD (1999), Chapter 1, Employment outlook, OECD Paris.

[54] Sánchez-Mangas, R. and V. Sánchez-Marcos (2008). "Balancing family and work: The effect of cash benefits for working mothers." Labor Economics 15(6): 1127-42.

[55] Saraceno, C. (2010). "Social Inequalities in Facing Old-Age Dependency: A Bi-Generational Perspective." Journal of European Social Policy 20(1): 32-44.

[56] Sarceno, C. and M. Naldini (2007). Sociologia della famiglia, Ed. Il Mulino.

[57] Siaroff, A. (1994). "Work, Welfare and Gender Equality: a New Typology", in D. Sainsbury (ed.) Gendering Welfare States, pp. 82-100. London: Sage.

[58] Simonazzi, A (2009), New skills for new jobs? Status quo and perspectives for the elderly care sector in Europe, European Employment Observatory (EEO) Thematic Paper.

[59] Stern, S. (1995), "Estimating family long-term care decisions in the presence of endogenous child characteristics", The Journal of Human Resources, Vol. 30, No. 3, pp. 551-80.

[60] Stoker, T M (1985), 'Aggregation, structural change, and cross-section estimation', Journal of American Statistical Association, Vol. 80, pp. 720-29. 
[61] Tangian A. (2007) European flexicurity: concepts, methodology and policies. Transfer, 2007/4, $551-573$

[62] Vigdor, J.L. (2008), "Measuring Immigrant Assimilation in the United States", Civic Report, Center for Civic Innovation at Manhattan Institute.

[63] Ward, C. and Dale, A. (1992) 'Geographical Variation in Female Labour Force Participation: An Application of Multilevel Modelling', Regional Studies, 26, 243-255.

[64] Wolf, D.A. and B.J. Soldo (1994), "Married women's allocation of time to employment and care of elderly parents", The Journal of Human Resources, Vol. 29, No. 4, pp. 1259-76. 


\section{A APPENDIX 1}

\section{A.1 Vigdor index: methodological framework}

Let us define $D$ to be a binary variable taking the value 0 if the individual is in group 0,1 if he/she is in group 1. We are interested in assessing differences between group 0 and group 1 using a onedimensional measure of how different are the distributions of some characteristics $x$ between group 0 and 1.

Let us denote by $f_{o}(x)$ the density function of $x$ among group 0 individuals (reference group), $f_{1}(x)$ the density function of $x$ among group 1 individuals.

Vigdor (2008) estimates a model for

$$
P(D=1 \mid x)=\frac{p f_{1}(x)}{p f_{1}(x)+(1-p) p f_{0}(x)}=\frac{p f_{1}(x)}{f(x)}=\rho(x)
$$

where $p$ is the proportion of group 1 individuals in the population and $f(x)$ is the density function of $x$ in the population. A generalization of the Vidgor index which is between zero and one and is composition invariant (i.e. it does not depend on $p$ ) is

$$
I=2 \int \frac{f_{0}(x) f_{1}(x)}{f_{0}(x)+f_{1}(x)} d x=2 \int \frac{1}{1+g(x)} f_{1}(x) d x
$$

Such an analysis is based on the ratio $g(x)=\frac{f_{1}(x)}{f_{0}(x)}$ which will be equal to 1 if group 0 and 1 have the same distribution of $x$. This implies that any difference in the observed $x$ will result in a discrepancy between group 0 and 1 in the synthetic index.

An important empirical issue is that there might be some characteristics $z$ whose differences between group 0 and 1 are not appropriate to take into consideration in infer a behavioral difference between group 0 and 1 . For example, we do not want to label differences in the age structures between two groups as differences in labor market behavior between the two groups. The unconditional distribution of $x$ (as in (4)) will be different if individuals in group 0 and 1 have a different distribution of $z$. An analysis based on (4) would be misleading. For example, if group 0 and group 1 are women and men, we do not want to capture differences in labor market performance between women and men due to different gender population structure. Gender demographic trends are correlated to differences in employment, labour market participation or job types, but they are not a matter of research themselves. Therefore, we need to work with the distribution of $x$ given $z$.

Denote by $f_{o}(x \mid z)$ the density function of $x$ given $z$ among group 0 individuals, $f_{1}(x \mid z)$ the density function of $x$ given $z$ among group 1 individuals. Define the marginal distributions of $z$ among group 0 and $1, h_{o}(z)$ and $h_{1}(z)$ respectively. We are thus interested in the ratio between 
density functions

$$
g(x \mid z)=\frac{f_{1}(x \mid z)}{f_{0}(x \mid z)}=\frac{f_{1}(x, z)}{f_{0}(x, z)} \frac{h_{o}(z)}{h_{1}(z)} .
$$

A generalization of the Vidgor index which allows for the presence of $z$ variables, while remaining composition invariant, is ${ }^{33}$

$$
I=2 \int \frac{1}{1+g(x \mid z)} f_{1}(x \mid z) h_{1}(z) d x d z
$$

Empirically, one has to get an estimate of $g(x \mid z)$. One way to proceed is as follows.

First, estimate a probit model for being an individual of group 1 on $x$ and $z$

$$
P(D=1 \mid x, z)=\frac{p f_{1}(x, z)}{p f_{1}(x, z)+(1-p) f_{0}(x, z)}=\frac{p f_{1}(x, z)}{f(x, z)}=\rho(x, z) .
$$

We can write

$$
\frac{f_{1}(x, z)}{f_{0}(x, z)}=\frac{\rho(x, z)}{[1-\rho(x, z)]} \frac{(1-p)}{p} .
$$

Substituting into (5), we have that

$$
g(x \mid z)=\frac{\rho(x, z)}{[1-\rho(x, z)]} \frac{(1-p)}{p} \frac{h_{o}(z)}{h_{1}(z)} .
$$

Second, estimate a probit model for being an individual of group 1 conditional on $z$ alone

$$
P(D=1 \mid z)=\frac{p h_{1}(z)}{p h_{1}(z)+(1-p) h_{0}(z)}=\varphi(z)
$$

We can write

$$
\frac{h_{o}(z)}{h_{1}(z)}=\frac{\varphi(z)}{[1-\varphi(z)]} \frac{(1-p)}{p}
$$

Substituting into (8) we have that

$$
g(x \mid z)=\frac{\rho(x, z)}{[1-\rho(x, z)]} \frac{[1-\varphi(z)]}{\varphi(z)} .
$$

In short, the relative densities of $x$ conditional on $z$ can be estimated from the predicted probabilities of two probit models for being an individual in group 1, one conditional on $x$ and $z$ and the other conditional on $z$ alone.

\footnotetext{
${ }^{33}$ The Vidgor index (Vidgor, 2008) is derived for a value of $\mathrm{p}=0.5$ and does not explicity deal with differences between $x$ and $z$ variables.
} 
Having $g(x \mid z)$ on hand, the average value of the transformation $\frac{1}{1+g(x \mid z)}$ across group 1 individuals, will then give the synthetic index $(6) .^{34}$

\section{A.2 Adaptation to our setting}

In our analysis we define $D$ as a dummy taking value 1 if the individual is female (disadvantaged group) and 0 otherwise. We consider two $x$ variables, $x_{k}, k=1,2$ :

- $x_{1}$ : dummy taking value 1 if the individual is inactive, and 0 if active (participation rate);

- $x_{2}$ : dummy taking value 1 if the active individual is employed, and 0 if unemployed (unemployment rate).

We use as control variables $z$ the individual education level, marital status, partner education, number of children and age.

We thus derive two synthetic indicators (activity index and employment index) for each European country and each year between 1994-2000 (ECHP) and between 2004-2009 (EU-SILC) and we perform T-test statistics to assess significant difference between the begin and the end of the observed time window. Tables in Appendix 3 collects the complete list of results.

${ }^{34}$ Algan et al. (2012) use this analysis to study cultural and economic integration patterns of immigrants in Europe. 


\section{B APPENDIX 2}

\section{B.1 An algebric decompostion}

Let us consider model 3 :

$$
y_{i j}^{t}=\beta_{0 j}^{t}+\beta_{11 j}^{t} C H I L D_{i j}^{t}+\beta_{12 j}^{t} E L D E R L Y_{i j}^{t}+\boldsymbol{\beta}_{2} / \mathbf{x}_{2 i j}^{t}+\varepsilon_{i j}^{t}
$$

where

$$
\begin{aligned}
& \beta_{0 j}^{t}=\delta_{0}+\delta_{1} I N S T_{j}^{t}+\delta_{2} P O L_{j}^{t}+\nu_{j}^{t} \\
& \beta_{11 j}^{t}=\gamma_{10}+\gamma_{11} I N S T_{j}^{t}+\gamma_{12} P O L_{j}^{t}+v_{1 j}^{t} \\
& \beta_{12 j}^{t}=\gamma_{20}+\gamma_{21} I N S T_{j}^{t}+\gamma_{22} P O L_{j}^{t}+v_{2 j}^{t}
\end{aligned}
$$

For simplicity of exposition, let us define $\mathbf{x}_{1 i j}^{t}$ a vector of individual characteristics whose impact depends on macro-factors (which in our model 3 include CHILD and ELDERLY).

We obtain:

$$
y_{i j}^{t}=\beta_{0 j}^{t}+\left(\mathbf{x}_{1 i j}^{t}\right) \prime \boldsymbol{\beta}_{1 j}^{t}+\left(\mathbf{x}_{2 i j}^{t}\right) \prime \boldsymbol{\beta}_{2 j}^{t}+\varepsilon_{i j}^{t}
$$

with:

$$
\begin{aligned}
& \beta_{0 j}^{t}=\delta_{0}^{t}+\left(\mathbf{z}_{1 i j}^{t}\right) / \boldsymbol{\delta}_{1 j}^{t}+\nu_{j}^{t} \\
& \boldsymbol{\beta}_{1 j}^{t}=\gamma_{0}^{t}+\left(\mathbf{z}_{1 i j}^{t}\right) / \gamma_{1 j}^{t}+\boldsymbol{v}_{j}^{t}
\end{aligned}
$$

Hence:

$$
y_{i j}^{t}=\delta_{0}^{t}+\left(\mathbf{z}_{1 i j}^{t}\right) / \delta_{1 j}^{t}+\left(\mathbf{x}_{1 i j}^{t}\right) / \gamma_{0}^{t}+\left(\mathbf{x}_{1 i j}^{t}\right) / \gamma_{1 j}^{t}\left(\mathbf{z}_{1 i j}^{t}\right) /+\left(\mathbf{x}_{2 i j}^{t}\right) / \boldsymbol{\beta}_{2 j}^{t}+R^{t}
$$

with: $\left(\mathbf{x}_{1 i j}^{t}, \boldsymbol{\beta}_{1 j}^{t}, \boldsymbol{\gamma}_{0}^{t}, \boldsymbol{v}_{1 j}^{t}\right)$ as $m \times 1$ vectors; $\left(\mathbf{x}_{2 i j}^{t}, \boldsymbol{\beta}_{2 j}^{t}\right)$ as $n \times 1$ vectors; $\left(\mathbf{z}_{1 i j}^{t}, \boldsymbol{\gamma}_{1 j}^{t}, \boldsymbol{\delta}_{1 j}^{t}\right)$ as $p \times 1$ vectors.

Let us take first-differences 


$$
\begin{aligned}
y_{i j}^{t}-y_{i j}^{t-1}= & \left(\delta_{0}^{t}-\delta_{0}^{t-1}\right)+\left[\left(\mathbf{z}_{1 i j}^{t}\right) \prime\left(\boldsymbol{\delta}_{1 j}^{t}-\boldsymbol{\delta}_{1 j}^{t-1}\right)+\left(\mathbf{z}_{1 i j}^{t}-\mathbf{z}_{1 i j}^{t-1}\right) \prime \boldsymbol{\delta}_{1 j}^{t-1}\right] \\
& +\left[\left(\mathbf{x}_{1 i j}^{t}\right) \prime\left(\boldsymbol{\gamma}_{0}^{t}-\boldsymbol{\gamma}_{0}^{t-1}\right)+\left(\mathbf{x}_{1 i j}^{t}-\mathbf{x}_{1 i j}^{t-1}\right) \prime \gamma_{0}^{t-1}\right] \\
& +\left[\left(\mathbf{x}_{2 i j}^{t}\right) \prime\left(\boldsymbol{\beta}_{2}^{t}-\boldsymbol{\beta}_{2}^{t-1}\right)+\left(\mathbf{x}_{2 i j}^{t}-\mathbf{x}_{2 i j}^{t-1}\right) \prime \boldsymbol{\beta}_{2}^{t-1}\right] \\
& +\left[\left(\mathbf{x}_{1 i j}^{t}\right) \prime\left(\boldsymbol{\gamma}_{1}^{t}-\boldsymbol{\gamma}_{1}^{t-1}\right) \mathbf{z}_{1 i j}^{t}+\left(\mathbf{x}_{1 i j}^{t}\left(\mathbf{z}_{1 i j}^{t}\right) \prime-\mathbf{x}_{1 i j}^{t-1}\left(\mathbf{z}_{1 i j}^{t-1}\right) \prime\right) \boldsymbol{\gamma}_{1}^{t-1}\right] \\
& +\left[R^{t}-R^{t-1}\right]
\end{aligned}
$$

The model 12 is equivalent to Stoker (1985), which decomposes the change of an aggregate variable (here the proportion of women who participate) into a change of the behavioural micro model (coefficients of 11 foe a series of cross-sections) and a change in the distribution of the micro variables (education, fertility, marital status, etc.). Since our aim is to quantify the role of changes in macro-factors on female decisions, we impose that the coefficient estimates of model 12 do not vary over time: in this way, we are able to use our multilevel model 3 to disentangle how much of changes in behaviour over time depends on changes in policy regulations. ${ }^{35}$ In other words, we apply the following restrictions to model 12:

- $\delta_{0}^{t}=\delta_{0}^{t-1}=\bar{\delta}_{0}$;

- $\boldsymbol{\beta}_{2}^{t}=\boldsymbol{\beta}_{2}^{t-1}=\overline{\boldsymbol{\beta}}_{2}$;

- $\gamma_{0}^{t}=\gamma_{0}^{t-1}=\bar{\gamma}_{0}$

- $\gamma_{1}^{t}=\gamma_{1}^{t-1}=\bar{\gamma}_{1}$;

- $\boldsymbol{\delta}_{1}^{t}=\boldsymbol{\delta}_{1}^{t-1}=\overline{\boldsymbol{\delta}}_{1}$;

- $\boldsymbol{\delta}_{0}^{t}=\boldsymbol{\delta}_{0}^{t-1}=\overline{\boldsymbol{\delta}}_{0}$

The simplyfied model is

\footnotetext{
${ }^{35}$ Through this simplification, we neglet variations on the coefficient estimates due to changes on preferences which are not related to macro-factors.

Since our aim is to quantify the role of changes in macro-factors on female decisions, this simplification does not affect our results.
} 


$$
\begin{aligned}
y_{i j}^{t}-y_{i j}^{t-1}= & {\left[\left(\mathbf{x}_{2 i j}^{t}-\mathbf{x}_{2 i j}^{t-1}\right) / \overline{\boldsymbol{\beta}}_{2}\right]+} \\
& +\left[\left(\mathbf{z}_{j}^{t}-\mathbf{z}_{j}^{t-1}\right) / \overline{\boldsymbol{\delta}}_{1}+\left(\mathbf{z}_{j}^{t}-\mathbf{z}_{j}^{t-1}\right) / \bar{\gamma}_{1}\left(\mathbf{x}_{1 i j}^{t-1}\right)\right] \\
& +\left[\left(\mathbf{x}_{1 i j}^{t}-\mathbf{x}_{1 i j}^{t-1}\right) / \bar{\gamma}_{0}+\left(\mathbf{z}_{1 i j}^{t}\right) / \bar{\gamma}_{1}\left(\mathbf{x}_{1 i j}^{t}-\mathbf{x}_{1 i j}^{t-1}\right)\right] \\
& +\left[R^{t}-R^{t-1}\right] \\
\equiv & \Delta \text { individual characteristics } \mathbf{x}_{2} \text { whose effect does not depend on macro factors } z \\
& +\Delta \text { in macro factors } z+ \\
& +\Delta \text { individual characteristics } \mathbf{x}_{1} \text { whose effect depends on macro factors } z \\
& +\Delta \text { residual component }
\end{aligned}
$$




\section{APPENDIX 3}

\section{Synthetic indicator: complete list of results}

Table C1 - Activity gap by country and year

\begin{tabular}{|c|c|c|c|c|c|c|c|c|c|c|c|c|c|c|}
\hline & \multicolumn{14}{|c|}{ Year } \\
\hline Country & 1994 & 1995 & 1996 & 1997 & 1998 & 1999 & 2000 & 2004 & 2005 & 2006 & 2007 & 2008 & 2009 & P-VALUE \\
\hline $\mathrm{AT}$ & & 0.8742 & 0.9031 & 0.9068 & 0.8954 & 0.9139 & 0.9192 & 0.9161 & 0.9126 & 0.9176 & 0.9232 & 0.9260 & 0.9443 & 0.0000 \\
\hline $\mathrm{BE}$ & 0.9427 & 0.9394 & 0.9384 & 0.9348 & 0.9550 & 0.9547 & 0.9555 & 0.9587 & 0.9676 & 0.9685 & 0.9749 & 0.9763 & 0.9754 & 0.0000 \\
\hline $\mathrm{DE}$ & 0.9622 & 0.9622 & 0.9622 & 0.9622 & 0.9622 & 0.9622 & 0.9622 & & 0.9622 & 0.9622 & 0.9622 & 0.9622 & 0.9622 & 0.5761 \\
\hline DK & 0.9858 & 0.9844 & 0.9783 & 0.9829 & 0.9859 & 0.9897 & 0.9899 & 0.9834 & 0.9931 & 0.9905 & 0.9936 & 0.9907 & 0.9984 & 0.0000 \\
\hline $\mathrm{ES}$ & 0.7959 & 0.7916 & 0.7958 & 0.8054 & 0.8152 & 0.8328 & 0.8408 & 0.8961 & 0.9021 & 0.9147 & 0.9285 & 0.9391 & 0.9454 & 0.0000 \\
\hline FI & & & 0.9975 & 0.9972 & 0.9943 & 0.9933 & 0.9954 & 0.9872 & 0.9889 & 0.9884 & 0.9869 & 0.9856 & 0.9811 & 0.0000 \\
\hline FR & 0.9521 & 0.9293 & 0.9234 & 0.9280 & 0.9349 & 0.9437 & 0.9444 & 0.9797 & 0.9824 & 0.9874 & 0.9888 & & 0.9843 & 0.0000 \\
\hline GR & 0.8104 & 0.8167 & 0.8089 & 0.8197 & 0.8266 & 0.8114 & 0.8405 & 0.8937 & 0.9000 & 0.9005 & 0.9073 & 0.9148 & 0.9201 & 0.0000 \\
\hline IE & 0.7166 & 0.7383 & 0.7744 & 0.7903 & 0.8129 & 0.8430 & 0.8632 & 0.9094 & 0.9020 & 0.8871 & 0.9106 & 0.9048 & 0.9094 & 0.0000 \\
\hline IT & 0.8110 & 0.8287 & 0.8269 & 0.8398 & 0.8477 & 0.8604 & 0.8499 & 0.9275 & 0.9191 & 0.9173 & 0.9213 & 0.9203 & 0.9287 & 0.0000 \\
\hline $\mathrm{LU}$ & & 0.7657 & 0.7573 & 0.7883 & 0.7929 & 0.7949 & 0.8084 & 0.8741 & 0.8829 & 0.8844 & 0.9146 & 0.9166 & 0.9128 & 0.0000 \\
\hline NL & 0.9311 & 0.9608 & 0.9567 & 0.9623 & 0.9708 & 0.9706 & 0.9676 & & 0.8974 & 0.9523 & 0.9596 & 0.9672 & 0.9747 & 0.0000 \\
\hline PT & 0.8719 & 0.8894 & 0.9058 & 0.9132 & 0.9151 & 0.9278 & 0.9279 & 0.9537 & 0.9614 & 0.9649 & 0.9727 & 0.9638 & 0.9657 & 0.0000 \\
\hline $\mathrm{SE}$ & & & & 0.9962 & 0.9962 & 0.9962 & 0.9962 & 0.9962 & 0.9962 & 0.9962 & 0.9962 & 0.9962 & 0.9962 & 0.6140 \\
\hline UK & 0.9521 & 0.9578 & 0.9572 & 0.9533 & 0.9583 & 0.9622 & 0.9621 & & 0.9649 & 0.9545 & 0.9738 & 0.9686 & 0.9693 & 0.0008 \\
\hline
\end{tabular}


Table C2 - Unemployment gap by country and year

\begin{tabular}{|c|c|c|c|c|c|c|c|c|c|c|c|c|c|c|}
\hline & \multicolumn{14}{|c|}{ Year } \\
\hline Country & 1994 & 1995 & 1996 & 1997 & 1998 & 1999 & 2000 & 2004 & 2005 & 2006 & 2007 & 2008 & 2009 & P-VALUE \\
\hline$\overline{\mathrm{AT}}$ & & 1,0000 & 0,9999 & 1,0000 & 0,9987 & 1,0000 & 1,0000 & 1,0000 & 0,9991 & 1,0000 & 1,0000 & 1,0000 & 1,0000 & 0.2003 \\
\hline $\mathrm{BE}$ & 0,9887 & 0,9887 & 0,9887 & 0,9887 & 0,9887 & 0,9887 & 0,9887 & 0,9887 & 0,9887 & 0,9887 & 0,9887 & 0,9887 & 0,9887 & 0.1005 \\
\hline $\mathrm{DE}$ & 0,9986 & 0,9978 & 0,9987 & 0,9999 & 0,9993 & 0,9989 & 0,9997 & & 0,9978 & 1,0000 & 0,9993 & 0,9999 & 1,0000 & 0.0001 \\
\hline DK & 0,9975 & 0,9872 & 0,9946 & 0,9925 & 0,9931 & 0,9961 & 0,9920 & 0,9999 & 0,9994 & 0,9982 & 0,9976 & 0,9992 & 1,0000 & 0.0129 \\
\hline $\mathrm{ES}$ & 0,9951 & 0,9939 & 0,9943 & 0,9948 & 0,9945 & 0,9912 & 0,9868 & 0,9833 & 0,9844 & 0,9852 & 0,9848 & 0,9949 & 0,9987 & 0.0121 \\
\hline FI & & & 1,0000 & 1,0000 & 1,0000 & 1,0000 & 1,0000 & 1,0000 & 1,0000 & 1,0000 & 1,0000 & 1,0000 & 1,0000 & 0.2797 \\
\hline $\mathrm{FR}$ & 0,9964 & 0,9926 & 0,9949 & 0,9931 & 0,9902 & 0,9895 & 0,9904 & 0,9997 & 0,9982 & 0,9959 & 0,9958 & & 0,9999 & 0.0008 \\
\hline GR & 0,9788 & 0,9809 & 0,9830 & 0,9851 & 0,9865 & 0,9870 & 0,9922 & 0,9870 & 0,9866 & 0,9845 & 0,9872 & 0,9920 & 0,9932 & 0.0005 \\
\hline $\mathrm{IE}$ & 0,9686 & 0,9722 & 0,9771 & 0,9688 & 0,9780 & 0,9901 & 0,9996 & 0,9924 & 0,9904 & 0,9925 & 0,9945 & 0,9860 & 0,9825 & 0.0011 \\
\hline IT & 0,9948 & 0,9961 & 0,9953 & 0,9926 & 0,9948 & 0,9935 & 0,9954 & 0,9933 & 0,9921 & 0,9914 & 0,9920 & 0,9912 & 0,9920 & 0.0869 \\
\hline $\mathrm{LU}$ & & 1,0000 & 1,0000 & 1,0000 & 1,0000 & 1,0000 & 1,0000 & 1,0000 & 1,0000 & 1,0000 & 1,0000 & 1,0000 & 1,0000 & 0.3528 \\
\hline NL & 0,9765 & 0,9637 & 0,9718 & 0,9702 & 0,9735 & 0,9704 & 0,9801 & & 0,9997 & 0,9997 & 1,0000 & 1,0000 & 0,9998 & 0.0000 \\
\hline $\mathrm{PT}$ & 0,9944 & 0,9983 & 0,9939 & 0,9987 & 0,9968 & 0,9981 & 0,9988 & 0,9994 & 0,9954 & 0,9984 & 0,9992 & 0,9969 & 0,9997 & 0.0226 \\
\hline $\mathrm{SE}$ & & & & 1,0000 & 1,0000 & 1,0000 & 1,0000 & 1,0000 & 1,0000 & 1,0000 & 1,0000 & 1,0000 & 1,0000 & 0.9503 \\
\hline UK & 0,9865 & 0,9966 & 0,9926 & 0,9965 & 0,9955 & 0,9956 & 0,9996 & & 0,9989 & 0,9954 & 0,9967 & 0,9967 & 0,9959 & 0.0000 \\
\hline
\end{tabular}


Table 1. Summary statistics: female sample`

\begin{tabular}{|c|c|c|c|c|c|c|}
\hline & Variable & Obs & Mean & Std. Dev. & Min & $\operatorname{Max}$ \\
\hline \multirow{12}{*}{ Individual Characteristics } & employed & 851010 & 0.594 & 0.491 & 0 & 1 \\
\hline & active & 851010 & 0.656 & 0.475 & 0 & 1 \\
\hline & male & 851010 & 0.000 & 0.000 & 0 & 0 \\
\hline & age & 851010 & 44.269 & 11.078 & 25 & 64 \\
\hline & ISCED03 & 832447 & 0.382 & 0.486 & 0 & 1 \\
\hline & ISCED35 & 832447 & 0.344 & 0.475 & 0 & 1 \\
\hline & ISCED57 & 832447 & 0.274 & 0.446 & 0 & 1 \\
\hline & single & 844864 & 0.189 & 0.392 & 0 & 1 \\
\hline & incouple & 844864 & 0.687 & 0.464 & 0 & 1 \\
\hline & separated & 844864 & 0.018 & 0.132 & 0 & 1 \\
\hline & divorced & 844864 & 0.067 & 0.250 & 0 & 1 \\
\hline & widowed & 844864 & 0.039 & 0.193 & 0 & 1 \\
\hline \multirow{10}{*}{ Household Characteritsics } & children & 851010 & 0.713 & 1.008 & 0 & 15 \\
\hline & child & 851010 & 0.422 & 0.494 & 0 & 1 \\
\hline & child06 & 851010 & 0.179 & 0.383 & 0 & 1 \\
\hline & child03 & 851010 & 0.096 & 0.295 & 0 & 1 \\
\hline & child36 & 851010 & 0.113 & 0.317 & 0 & 1 \\
\hline & child614 & 851010 & 0.259 & 0.438 & 0 & 1 \\
\hline & old70 & 851010 & 0.060 & 0.238 & 0 & 1 \\
\hline & pISCED03 & 851010 & 0.276 & 0.447 & 0 & 1 \\
\hline & pISCED35 & 851010 & 0.258 & 0.438 & 0 & 1 \\
\hline & pISCED57 & 851010 & 0.198 & 0.398 & 0 & 1 \\
\hline \multirow{2}{*}{ Trend } & year & 851010 & 2003 & 4.983 & 1994 & 2009 \\
\hline & cycle & 842730 & 0.006 & 1.958 & -8.636 & 4.172 \\
\hline \multirow{15}{*}{ Country of residence } & DK & 851010 & 0.044 & 0.206 & 0 & 1 \\
\hline & NL & 851010 & 0.070 & 0.255 & 0 & 1 \\
\hline & $\mathrm{BE}$ & 851010 & 0.045 & 0.207 & 0 & 1 \\
\hline & FR & 851010 & 0.074 & 0.262 & 0 & 1 \\
\hline & $\mathrm{IE}$ & 851010 & 0.043 & 0.203 & 0 & 1 \\
\hline & IT & 851010 & 0.156 & 0.362 & 0 & 1 \\
\hline & GR & 851010 & 0.060 & 0.237 & 0 & 1 \\
\hline & $\mathrm{ES}$ & 851010 & 0.111 & 0.314 & 0 & 1 \\
\hline & $\mathrm{PT}$ & 851010 & 0.054 & 0.227 & 0 & 1 \\
\hline & $\mathrm{AT}$ & 851010 & 0.043 & 0.204 & 0 & 1 \\
\hline & FI & 851010 & 0.068 & 0.252 & 0 & 1 \\
\hline & $\mathrm{SE}$ & 851010 & 0.048 & 0.213 & 0 & 1 \\
\hline & $\mathrm{DE}$ & 851010 & 0.087 & 0.282 & 0 & 1 \\
\hline & $\mathrm{LU}$ & 851010 & 0.035 & 0.183 & 0 & 1 \\
\hline & UK & 851010 & 0.062 & 0.241 & 0 & 1 \\
\hline
\end{tabular}

- ISCED02 (pISCED02): lower secondary education of the woman (of her partner); ISCED35 (pISCED35): upper secondary education of the woman (of her partner); ISCED57 (pISCED57): tertiary education of the woman (of her partner). 
Table 2. Summary statistics: male sample ${ }^{\bullet}$

\begin{tabular}{|c|c|c|c|c|c|c|}
\hline & Variable & Obs & Mean & Std. Dev. & Min & $\operatorname{Max}$ \\
\hline \multirow{12}{*}{ Individual Characteristics } & employed & 806357 & 0.797 & 0.402 & 0 & 1 \\
\hline & active & 806357 & 0.857 & 0.350 & 0 & 1 \\
\hline & male & 806357 & 1.000 & 0.000 & 1 & 1 \\
\hline & age & 806357 & 44.229 & 11.137 & 25 & 64 \\
\hline & ISCED03 & 788367 & 0.360 & 0.480 & 0 & 1 \\
\hline & ISCED35 & 788367 & 0.368 & 0.482 & 0 & 1 \\
\hline & ISCED57 & 788367 & 0.273 & 0.445 & 0 & 1 \\
\hline & single & 799834 & 0.257 & 0.437 & 0 & 1 \\
\hline & incouple & 799834 & 0.675 & 0.468 & 0 & 1 \\
\hline & separated & 799834 & 0.013 & 0.112 & 0 & 1 \\
\hline & divorced & 799834 & 0.046 & 0.209 & 0 & 1 \\
\hline & widowed & 799834 & 0.010 & 0.098 & 0 & 1 \\
\hline \multirow{10}{*}{ Household Characteritsics } & children & 806357 & 0.435 & 0.925 & 0 & 14 \\
\hline & child & 806357 & 0.225 & 0.418 & 0 & 1 \\
\hline & child06 & 806357 & 0.180 & 0.384 & 0 & 1 \\
\hline & child03 & 806357 & 0.100 & 0.300 & 0 & 1 \\
\hline & child36 & 806357 & 0.112 & 0.315 & 0 & 1 \\
\hline & child 614 & 806357 & 0.244 & 0.430 & 0 & 1 \\
\hline & old70 & 806357 & 0.061 & 0.239 & 0 & 1 \\
\hline & pISCED03 & 806357 & 0.278 & 0.448 & 0 & 1 \\
\hline & pISCED35 & 806357 & 0.261 & 0.439 & 0 & 1 \\
\hline & pISCED57 & 806357 & 0.198 & 0.398 & 0 & 1 \\
\hline \multirow{2}{*}{ Trend } & year & 806357 & 2003.000 & 4.985 & 1994 & 2009 \\
\hline & cycle & 798435 & 0.012 & 1.959 & -8.636 & 4.172 \\
\hline \multirow{15}{*}{ Country of residence } & DK & 806357 & 0.045 & 0.207 & 0 & 1 \\
\hline & NL & 806357 & 0.068 & 0.253 & 0 & 1 \\
\hline & $\mathrm{BE}$ & 806357 & 0.044 & 0.205 & 0 & 1 \\
\hline & FR & 806357 & 0.073 & 0.261 & 0 & 1 \\
\hline & $\mathrm{IE}$ & 806357 & 0.043 & 0.202 & 0 & 1 \\
\hline & IT & 806357 & 0.159 & 0.366 & 0 & 1 \\
\hline & GR & 806357 & 0.060 & 0.238 & 0 & 1 \\
\hline & $\mathrm{ES}$ & 806357 & 0.111 & 0.314 & 0 & 1 \\
\hline & $\mathrm{PT}$ & 806357 & 0.053 & 0.224 & 0 & 1 \\
\hline & $\mathrm{AT}$ & 806357 & 0.043 & 0.203 & 0 & 1 \\
\hline & FI & 806357 & 0.073 & 0.260 & 0 & 1 \\
\hline & $\mathrm{SE}$ & 806357 & 0.049 & 0.216 & 0 & 1 \\
\hline & $\mathrm{DE}$ & 806357 & 0.083 & 0.276 & 0 & 1 \\
\hline & $\mathrm{LU}$ & 806357 & 0.036 & 0.187 & 0 & 1 \\
\hline & UK & 806357 & 0.059 & 0.235 & 0 & 1 \\
\hline
\end{tabular}

- ISCED02 (pISCED02): lower secondary education of the man (of his partner); ISCED35 (pISCED35): upper secondary education of the man (of his partner); ISCED57 (pISCED57): tertiary education of the man (of his partner). 
Table 3: Female activity by welfare regimes

ALL

LIBERAL

CONTINENTAL

DEMOCRATIC

SOUTHERN

\begin{tabular}{|c|c|c|c|c|c|c|c|c|c|c|c|c|c|c|c|}
\hline & Coef. & & St.Err. & Coef. & & St.Err. & Coef. & & St.Err. & Coef. & & St.Err. & Coef. & & St.Err. \\
\hline \multicolumn{16}{|l|}{ Marital status } \\
\hline \multicolumn{16}{|l|}{ Single } \\
\hline incouple & -0.071 & $* * *$ & 0.003 & -0.009 & & 0.010 & -0.098 & $* * *$ & 0.005 & -0.022 & $* * *$ & 0.005 & -0.109 & $* * *$ & 0.006 \\
\hline separated & 0.057 & $* * *$ & 0.007 & 0.022 & & 0.018 & 0.056 & $* * *$ & 0.016 & -0.006 & & 0.024 & 0.100 & $* * *$ & 0.009 \\
\hline divorced & 0.05 & $* * *$ & 0.004 & 0.036 & $* * *$ & 0.012 & 0.033 & $* * *$ & 0.006 & -0.013 & * & 0.007 & 0.125 & $* * *$ & 0.008 \\
\hline widowed & -0.067 & $* * *$ & 0.006 & 0.019 & & 0.013 & -0.100 & $* * *$ & 0.011 & -0.021 & $*$ & 0.013 & -0.109 & $* * *$ & 0.009 \\
\hline \multicolumn{16}{|l|}{ Children } \\
\hline \multicolumn{16}{|l|}{ No children } \\
\hline children & -0.038 & $* * *$ & 0.003 & -0.027 & $* *$ & 0.012 & -0.036 & $* * *$ & 0.005 & -0.036 & $* * *$ & 0.006 & -0.039 & $* * *$ & 0.004 \\
\hline child & 0.043 & $* * *$ & 0.005 & 0.064 & $* * *$ & 0.017 & 0.061 & $* * *$ & 0.008 & 0.073 & $* * *$ & 0.008 & 0.035 & $* * *$ & 0.007 \\
\hline child03 & -0.174 & $* * *$ & 0.004 & -0.275 & $* * *$ & 0.012 & -0.254 & $* * *$ & 0.007 & -0.173 & $* * *$ & 0.007 & -0.073 & $* * *$ & 0.006 \\
\hline child36 & -0.088 & $* * *$ & 0.003 & -0.177 & $* * *$ & 0.011 & -0.082 & $* * *$ & 0.006 & -0.002 & & 0.006 & -0.064 & $* * *$ & 0.005 \\
\hline child614 & -0.067 & $* * *$ & 0.003 & -0.129 & $* * *$ & 0.008 & -0.064 & $* * *$ & 0.005 & 0.027 & $* * *$ & 0.005 & -0.061 & $* * *$ & 0.004 \\
\hline \multicolumn{16}{|l|}{ Co-habiting Elderly } \\
\hline \multicolumn{16}{|l|}{ no_elderly } \\
\hline old $70-80$ & -0.068 & $* * *$ & 0.005 & -0.183 & $* * *$ & 0.023 & -0.149 & $* * *$ & 0.014 & -0.151 & $* * *$ & 0.016 & -0.029 & $* * *$ & 0.006 \\
\hline old 80 & -0.025 & $* * *$ & 0.006 & -0.080 & $* * *$ & 0.032 & -0.036 & $* *$ & 0.017 & -0.121 & $* * *$ & 0.029 & -0.010 & & 0.008 \\
\hline \multicolumn{16}{|l|}{ Education } \\
\hline \multicolumn{16}{|l|}{ Low skilled } \\
\hline ISCED35 & 0.122 & $* * *$ & 0.002 & 0.177 & $* * *$ & 0.008 & 0.096 & $* * *$ & 0.004 & 0.091 & $* * *$ & 0.004 & 0.135 & $* * *$ & 0.003 \\
\hline ISCED57 & 0.214 & $* * *$ & 0.003 & 0.223 & $* * *$ & 0.008 & 0.176 & $* * *$ & 0.004 & 0.138 & $* * *$ & 0.005 & 0.266 & $* * *$ & 0.004 \\
\hline pISCED03 & -0.016 & $* * *$ & 0.003 & 0.035 & $* * *$ & 0.011 & 0.000 & & 0.007 & 0.049 & $* * *$ & 0.006 & -0.033 & $* * *$ & 0.006 \\
\hline pISCED35 & 0.039 & $* * *$ & 0.003 & 0.078 & $* * *$ & 0.009 & 0.044 & $* * *$ & 0.005 & 0.067 & $* * *$ & 0.005 & 0.017 & $* * *$ & 0.006 \\
\hline pISCED57 & 0.018 & $* * *$ & 0.004 & 0.042 & $* * *$ & 0.009 & 0.023 & $* * *$ & 0.006 & 0.058 & $* * *$ & 0.005 & 0.014 & $* *$ & 0.007 \\
\hline \multicolumn{16}{|l|}{ Age } \\
\hline \multicolumn{16}{|l|}{ Age_25-34 } \\
\hline age_35_44 & 0.052 & $* * *$ & 0.003 & 0.039 & $* * *$ & 0.009 & 0.067 & $* * *$ & 0.005 & 0.074 & $* * *$ & 0.005 & 0.034 & $* * *$ & 0.005 \\
\hline age_45_54 & -0.013 & $* * *$ & 0.003 & -0.056 & $* * *$ & 0.011 & 0.018 & $* * *$ & 0.006 & 0.089 & $* * *$ & 0.005 & -0.054 & $* * *$ & 0.005 \\
\hline age_55_64 & -0.295 & $* * *$ & 0.004 & -0.300 & $* * *$ & 0.012 & -0.301 & $* * *$ & 0.007 & -0.078 & $* * *$ & 0.007 & -0.366 & $* * *$ & 0.005 \\
\hline \multicolumn{16}{|l|}{ Macro } \\
\hline trend & 0.012 & $* * *$ & 0.001 & 0.008 & $* * *$ & 0.003 & 0.019 & $* * *$ & 0.001 & 0.004 & $* * *$ & 0.001 & 0.009 & $* * *$ & 0.001 \\
\hline cycle & 0.003 & $* * *$ & 0.001 & 0.000 & & 0.002 & 0.007 & $* * *$ & 0.001 & 0.000 & & 0.001 & -0.001 & & 0.001 \\
\hline \multicolumn{16}{|l|}{ UK } \\
\hline DK & 0.075 & $* * *$ & 0.005 & & & & & & & Ref. & & & & & \\
\hline $\mathrm{NL}$ & -0.039 & $* * *$ & 0.004 & & & & 0.008 & & 0.006 & & & & & & \\
\hline $\mathrm{BE}$ & 0.018 & $* * *$ & 0.004 & & & & 0.065 & $* * *$ & 0.005 & & & & & & \\
\hline FR & 0.078 & $* * *$ & 0.004 & & & & 0.128 & $* * *$ & 0.005 & & & & & & \\
\hline IE & -0.046 & $* * *$ & 0.005 & & & & Ref. & & & & & & & & \\
\hline $\mathrm{IT}$ & -0.077 & $* * *$ & 0.004 & & & & & & & & & & -0.292 & $* * *$ & 0.005 \\
\hline GR & -0.041 & $* * *$ & 0.004 & & & & & & & & & & -0.263 & $* * *$ & 0.006 \\
\hline $\mathrm{ES}$ & 0.012 & $* * *$ & 0.004 & & & & & & & & & & -0.201 & $* * *$ & 0.006 \\
\hline $\mathrm{PT}$ & 0.159 & $* * *$ & 0.004 & & & & & & & & & & Ref. & & \\
\hline $\mathrm{AT}$ & -0.053 & $* * *$ & 0.004 & & & & 0.001 & & 0.006 & & & & & & \\
\hline FI & 0.072 & $* * *$ & 0.004 & & & & & & & -0.002 & & 0.004 & & & \\
\hline $\mathrm{SE}$ & 0.1 & $* * *$ & 0.004 & & & & & & & 0.031 & $* * *$ & 0.004 & & & \\
\hline $\mathrm{DE}$ & 0.005 & & 0.004 & & & & 0.058 & $* * *$ & 0.006 & & & & & & \\
\hline $\mathrm{LU}$ & -0.04 & $* * *$ & 0.006 & & & & 0.008 & & 0.007 & & & & & & \\
\hline Observations & 81816 & & & 50464 & & & 328750 & & & 129536 & & & 309418 & & \\
\hline Log likelihood & -43284 & & & -26584 & & & -166126 & & & -60103 & & & -169704 & & \\
\hline pseudo - R2 & 0.148 & & & 0.123 & & & 0.142 & & & 0.086 & & & 0.174 & & \\
\hline Country dummies & & & & yes & & & Yes & & & yes & & & yes & & \\
\hline
\end{tabular}


Table 4: Female activity rate: trends and welfare regimes

ALL LIBERAL CONTINENTAL DEMOCRATIC

SOUTHERN

\begin{tabular}{|c|c|c|c|c|c|c|c|c|c|c|c|c|c|c|c|}
\hline & Coef. & & St.Err. & Coef. & & St.Err. & Coef. & & St.Err. & Coef. & & St.Err. & Coef. & & St.Err. \\
\hline \multicolumn{16}{|l|}{ Marital status } \\
\hline \multicolumn{16}{|l|}{ Single } \\
\hline Incouple & -0.021 & & 0.022 & 0.029 & \multirow[b]{2}{*}{$*$} & 0.074 & -0.065 & \multirow[t]{2}{*}{$*$} & 0.035 & \multicolumn{2}{|l|}{0.033} & 0.034 & \multicolumn{2}{|l|}{0.008} & 0.033 \\
\hline Separated & 0.055 & $* * *$ & 0.007 & 0.033 & & 0.017 & 0.021 & & 0.018 & \multicolumn{2}{|l|}{0.012} & 0.024 & 0.091 & $* * *$ & 0.009 \\
\hline Divorced & 0.029 & $* * *$ & 0.005 & 0.039 & $* * *$ & 0.013 & 0.006 & & 0.007 & -0.020 & \multirow[t]{2}{*}{$* * *$} & 0.007 & 0.114 & $* * *$ & 0.008 \\
\hline Widowed & -0.032 & $* * *$ & 0.006 & 0.022 & $*$ & 0.013 & -0.049 & $* * *$ & 0.010 & -0.009 & & 0.013 & -0.045 & $* * *$ & 0.008 \\
\hline \multicolumn{16}{|l|}{ Children } \\
\hline \multicolumn{16}{|l|}{ No children } \\
\hline Children & -0.032 & $* * *$ & 0.003 & -0.019 & \multirow{4}{*}{$\begin{array}{l}* * * \\
* * *\end{array}$} & 0.012 & -0.026 & $* * *$ & 0.006 & -0.038 & $* * *$ & 0.006 & -0.031 & \multirow[t]{2}{*}{$* * *$} & 0.004 \\
\hline Childd & 0.046 & $* * *$ & 0.017 & -0.001 & & 0.068 & 0.085 & $* * *$ & 0.030 & 0.146 & $* * *$ & 0.028 & 0.026 & & 0.023 \\
\hline child03d & -0.120 & $* * *$ & 0.026 & -0.313 & & 0.086 & -0.186 & $* * *$ & 0.044 & -0.381 & \multirow[t]{2}{*}{$* * *$} & 0.049 & -0.038 & \multirow[b]{2}{*}{$* * *$} & 0.034 \\
\hline child36d & -0.126 & $* * *$ & 0.024 & -0.245 & & 0.087 & -0.181 & $* * *$ & 0.041 & 0.001 & & 0.042 & -0.104 & & 0.031 \\
\hline child614d & -0.042 & $* *$ & 0.018 & -0.121 & $*$ & 0.068 & -0.040 & & 0.033 & -0.017 & & 0.036 & -0.058 & $* *$ & 0.024 \\
\hline trend ${ }^{*}$ child & 0.000 & & 0.001 & 0.004 & & 0.005 & -0.002 & & 0.002 & -0.005 & $* *$ & 0.002 & 0.000 & & 0.002 \\
\hline trend ${ }^{*}$ child03 & -0.003 & & 0.002 & 0.006 & & 0.007 & -0.002 & & 0.004 & 0.015 & $* * *$ & 0.003 & -0.002 & & 0.003 \\
\hline trend* ${ }^{*}$ child36 & 0.003 & & 0.002 & 0.006 & & 0.007 & 0.007 & $* *$ & 0.003 & -0.001 & & 0.003 & 0.005 & $*$ & 0.003 \\
\hline trend* ${ }^{*}$ child614 & -0.002 & & 0.001 & 0.000 & & 0.005 & -0.002 & & 0.003 & 0.003 & & 0.003 & 0.000 & & 0.002 \\
\hline Co-habiting Elderly & & & & & & & & & & & & & & & \\
\hline no elderly & & & & & & & & & & & & & & & \\
\hline old7080 & 0.031 & & 0.035 & -0.184 & & 0.175 & 0.015 & & 0.087 & -0.100 & & 0.111 & 0.028 & & 0.039 \\
\hline old 80 & -0.062 & & 0.044 & -0.015 & & 0.246 & -0.083 & & 0.119 & -0.062 & & 0.191 & -0.067 & & 0.046 \\
\hline trend ${ }^{*}$ old7080 & -0.008 & $* * *$ & 0.003 & 0.002 & & 0.013 & -0.011 & & 0.007 & -0.003 & & 0.008 & -0.006 & $* *$ & 0.003 \\
\hline trend ${ }^{*}$ old 80 & 0.004 & & 0.003 & -0.004 & & 0.019 & 0.005 & & 0.009 & -0.003 & & 0.014 & 0.005 & & 0.004 \\
\hline Education & & & & & & & & & & & & & & & \\
\hline Low skilled & & & & & & & & & & & & & & & \\
\hline ISCED35 & 0.074 & $* * *$ & 0.017 & 0.171 & $* * *$ & 0.065 & -0.018 & & 0.032 & 0.116 & $* * *$ & 0.033 & 0.124 & $* * *$ & 0.023 \\
\hline ISCED57 & 0.129 & $* * *$ & 0.021 & 0.156 & $* *$ & 0.073 & -0.002 & & 0.038 & 0.154 & $* * *$ & 0.036 & 0.223 & $* * *$ & 0.027 \\
\hline trend*ISCED35 & 0.006 & $* * *$ & 0.001 & 0.001 & & 0.006 & 0.012 & $* * *$ & 0.003 & 0.000 & & 0.003 & 0.002 & & 0.002 \\
\hline trend*ISCED57 & 0.010 & $* * *$ & 0.002 & 0.007 & & 0.006 & 0.019 & $* * *$ & 0.003 & 0.002 & & 0.003 & 0.004 & $* *$ & 0.002 \\
\hline pISCED03 & -0.036 & & 0.025 & 0.011 & & 0.097 & 0.022 & & 0.047 & 0.005 & & 0.046 & -0.065 & $*$ & 0.035 \\
\hline pISCED35 & -0.043 & $*$ & 0.024 & 0.039 & & 0.077 & 0.014 & & 0.039 & -0.010 & & 0.041 & -0.093 & $* * *$ & 0.036 \\
\hline pISCED57 & -0.029 & & 0.026 & 0.031 & & 0.080 & -0.024 & & 0.042 & -0.020 & & 0.045 & 0.004 & & 0.041 \\
\hline trend*pISCED03 & 0.003 & $*$ & 0.002 & 0.002 & & 0.008 & 0.000 & & 0.004 & 0.005 & & 0.004 & 0.004 & $*$ & 0.003 \\
\hline trend*pISCED35 & 0.009 & $* * *$ & 0.002 & 0.004 & & 0.006 & 0.004 & & 0.003 & 0.008 & $* * *$ & 0.003 & 0.011 & $* * *$ & 0.003 \\
\hline trend*pISCED57 & 0.006 & $* * *$ & 0.002 & 0.001 & & 0.006 & 0.006 & $*$ & 0.003 & 0.008 & $* *$ & 0.004 & 0.003 & & 0.003 \\
\hline Age & & & & & & & & & & & & & & & \\
\hline $25-34$ & & & & & & & & & & & & & & & \\
\hline $35-44$ & 0.006 & & 0.022 & 0.084 & & 0.079 & -0.061 & & 0.039 & 0.125 & $* * *$ & 0.037 & 0.017 & & 0.028 \\
\hline $45-54$ & -0.085 & $* * *$ & 0.023 & -0.129 & & 0.090 & -0.177 & $* * *$ & 0.039 & 0.125 & $* * *$ & 0.041 & -0.050 & $*$ & 0.031 \\
\hline $55-64$ & -0.383 & $* * *$ & 0.021 & -0.312 & $* * *$ & 0.089 & -0.529 & $* * *$ & 0.025 & 0.010 & & 0.043 & -0.291 & $* * *$ & 0.029 \\
\hline trend $^{*}(35-44)$ & 0.005 & $* * *$ & 0.002 & -0.003 & & 0.006 & 0.010 & $* * *$ & 0.003 & -0.004 & & 0.003 & 0.004 & $*$ & 0.002 \\
\hline trend $^{*}(45-54)$ & 0.008 & $* * *$ & 0.002 & 0.006 & & 0.007 & 0.016 & $* * *$ & 0.003 & -0.002 & & 0.004 & 0.005 & $* *$ & 0.002 \\
\hline trend $^{*}(55-64)$ & 0.011 & $* * *$ & 0.002 & 0.004 & & 0.007 & 0.025 & $* * *$ & 0.003 & -0.006 & $*$ & 0.003 & 0.005 & $*$ & 0.003 \\
\hline Macro & & & & & & & & & & & & & & & \\
\hline trend & 0.001 & & 0.002 & 0.000 & & 0.007 & -0.006 & & 0.004 & 0.006 & & 0.004 & 0.005 & $* *$ & 0.002 \\
\hline cycle & 0.005 & $* * *$ & 0.001 & 0.002 & & 0.002 & 0.007 & $* * *$ & 0.001 & 0.001 & $* *$ & 0.001 & 0.004 & $* * *$ & 0.001 \\
\hline Observations & 818168 & & & 50464 & & & 328750 & & & 129536 & & & 309418 & & \\
\hline Log likelihood & -47300 & 9.5 & & -27444 & & & -18669 & 5.4 & & -67324 & & & -18533 & 3.1 & \\
\hline pseudo - R2 & 0.128 & & & 0.117 & & & 0.122 & & & 0.084 & & & 0.132 & & \\
\hline Country dummies & yes & & & - & & & yes & & & yes & & & yes & & \\
\hline
\end{tabular}


Table 5. Description of macro policy and institutional indicators

\begin{tabular}{|c|c|c|c|}
\hline $\begin{array}{l}\text { Final } \\
\text { Variable }\end{array}$ & $\begin{array}{l}\text { Original } \\
\text { Varable }\end{array}$ & Description & Source \\
\hline \multirow{3}{*}{ Institutions } & $\begin{array}{l}\text { Employment } \\
\text { Protection } \\
\text { Legislation }\end{array}$ & $\begin{array}{l}\text { Composite indicator of employment protection which refers both to } \\
\text { regulations concerning hiring (e.g. rules favouring disadvantaged } \\
\text { groups, conditions for using temporary or fixed-term contracts, } \\
\text { training requirements) and firing (e.g. redundancy procedures, } \\
\text { mandated prenotification periods and severance payments, special } \\
\text { requirements for collective dismissals and short-time work } \\
\text { schemes). }\end{array}$ & $\begin{array}{l}\text { OECD, } \\
\text { various } \\
\text { years }\end{array}$ \\
\hline & $\begin{array}{l}\text { Passive } \\
\text { Labour } \\
\text { Market } \\
\text { Policies }\end{array}$ & $\begin{array}{l}\text { Sum of national expenditures on active labour market policies (in } \\
\text { percentage of national GDP), including: Out-of-work income } \\
\text { maintenance and support, Early retirement. }\end{array}$ & $\begin{array}{l}\text { OECD, } \\
\text { various } \\
\text { years }\end{array}$ \\
\hline & $\begin{array}{l}\text { Active } \\
\text { Labour } \\
\text { Market } \\
\text { Policies }\end{array}$ & $\begin{array}{l}\text { Sum of national expenditures on active labour market policies (in } \\
\text { percentage of national GDP), including: Training, Job Rotation } \\
\text { and Job Sharing, Employment incentives, Supported employment } \\
\text { and rehabilitation, Direct job creation, Start-up incentives. }\end{array}$ & $\begin{array}{l}\text { OECD, } \\
\text { various } \\
\text { years }\end{array}$ \\
\hline \multirow{3}{*}{ Policies } & $\begin{array}{l}\text { Elderly } \\
\text { Subsidies }\end{array}$ & $\begin{array}{l}\text { Sum of national transfers to the elderly population (per head at } \\
\text { constant prices }(2000) \text { and constant PPPs }(2000) \text {, in US dollars), } \\
\text { weighted by the percentage of old-age population (over } 70 \text { years } \\
\text { old) within the country. This set of policies includes: Old age cash } \\
\text { and in kind benefits, Residential care or Home-help services. }\end{array}$ & $\begin{array}{l}\text { OECD, } \\
\text { various } \\
\text { years }\end{array}$ \\
\hline & $\begin{array}{l}\text { Family } \\
\text { Susidies }\end{array}$ & $\begin{array}{l}\text { Sum of national expenditures on allowances and other type of } \\
\text { monthly transfers to the households (per family at constant prices } \\
\text { (2000) and constant PPPs(2000), in US dollars). We consider a } \\
\text { weighted sum of monthly family allowances for the first, second, } \\
\text { and third child in national currency, with weights equal to the } \\
\text { average number of children a woman would have if she lived to the } \\
\text { end of her childbearing years (conventionally considered to be } 15- \\
44 \text { but sometimes 15-49) and bore children at the prevailing rate } \\
\text { for each age during that period. Value of tax and benefit transfers } \\
\text { of one-earner-two-parent two-child families are considered. The } \\
\text { value was calculated by subtracting the disposable income (after } \\
\text { taxes and transfers) of a one-earner-two-parent-two-child family } \\
\text { from that of a comparable childless single earner. }\end{array}$ & $\begin{array}{l}\text { Anne H. } \\
\text { Gauthier, } \\
2011\end{array}$ \\
\hline & $\begin{array}{l}\text { Paternal } \\
\text { Leave }\end{array}$ & $\begin{array}{l}\text { Composite indicator of national expenditures on maternity, } \\
\text { parental, and child care leave schemes. It is a weighted sum of the } \\
\text { total number of weeks of maternity, parental and child-care leave, } \\
\text { with weights equal to the cash benefits paid during the leave as a } \\
\text { percent of female wages in manufacturing. }\end{array}$ & $\begin{array}{l}\text { Anne H. } \\
\text { Gauthier, } \\
2011\end{array}$ \\
\hline
\end{tabular}


Table 6. Principal Component Analysis: rotated factor loadings

\begin{tabular}{lccr}
\hline Variable & Factor1 & Factor2 & Uniqueness $^{*}$ \\
Elderly Subsidies & 0.2570 & & 0.9339 \\
Parental Leave & 0.8251 & & 0.3192 \\
Family Subsidies & 0.8399 & & 0.2946 \\
Employment Protection & & -0.1499 & 0.9775 \\
Legislation & & 0.9119 & 0.1684 \\
Passive Labour Market Policies & & 0.9215 & 0.1509 \\
Active Labour Market Policies & & 0 \\
\hline
\end{tabular}

* The variance of each original variable not captured by the factor is an error term called a uniqueness. Hence, the greater 'uniqueness' the lower the relevance of the variable in the resulting factor. 
Table 7: Two-Level probit regression: the impact policy \& institutions by age

\begin{tabular}{|c|c|c|c|c|c|c|c|c|c|c|c|c|}
\hline & \multicolumn{3}{|c|}{ ALL } & \multicolumn{3}{|c|}{$25-34$} & \multicolumn{3}{|c|}{$34-45$} & \multicolumn{3}{|c|}{$44-55$} \\
\hline & Coef. & & St.Err. & Coef. & & St.Err. & Coef. & & St.Err. & Coef. & & St.Err. \\
\hline INST & -0.006 & & 0.014 & -0.031 & & 0.037 & 0.008 & & 0.015 & 0.024 & & 0.015 \\
\hline POL & 0.003 & & 0.024 & -0.009 & & 0.045 & 0.013 & & 0.026 & 0.006 & & 0.020 \\
\hline INST $\times$ child06 & 0.015 & $* * *$ & 0.001 & 0.040 & $* * *$ & 0.002 & 0.002 & & 0.002 & 0.008 & & 0.006 \\
\hline POL $\times$ child06 & 0.000 & & 0.001 & 0.006 & $* * *$ & 0.002 & 0.003 & & 0.002 & 0.008 & & 0.006 \\
\hline INST $\times$ old70 & -0.020 & $* * *$ & 0.003 & -0.013 & $* *$ & 0.006 & -0.019 & $* * *$ & 0.005 & -0.023 & $* * *$ & 0.005 \\
\hline POL $\times$ old70 & -0.008 & $* *$ & 0.003 & -0.008 & & 0.007 & 0.004 & & 0.006 & -0.026 & $* * *$ & 0.005 \\
\hline VPC_overall & 0.056 & & & 0.199 & & & 0.063 & & & 0.042 & & \\
\hline VPC_level 2 & 0.426 & & & 0.675 & & & 0.439 & & & 0.439 & & \\
\hline
\end{tabular}

Table 8: Two-Level probit regression: the impact policy \& institutions by education

\begin{tabular}{|c|c|c|c|c|c|c|c|c|c|}
\hline & \multicolumn{3}{|c|}{ ISCED_03 } & \multicolumn{3}{|c|}{ ISCED_35 } & \multicolumn{3}{|c|}{ ISCED_57 } \\
\hline & Coef. & & St.Err. & Coef. & & St.Err. & Coef. & & St.Err. \\
\hline INST & 0.004 & & 0.028 & -0.012 & & 0.013 & -0.015 & $* * *$ & 0.014 \\
\hline POL & -0.021 & & 0.041 & -0.001 & & 0.024 & -0.010 & & 0.020 \\
\hline INST $\times$ child06 & 0.012 & $* * *$ & 0.003 & 0.014 & *** & 0.002 & 0.025 & $* * *$ & 0.002 \\
\hline POL $\times$ child06 & 0.001 & & 0.002 & 0.004 & $* *$ & 0.002 & 0.011 & $* * *$ & 0.002 \\
\hline INST $\times$ old70 & -0.041 & $* * *$ & 0.006 & -0.020 & $* * *$ & 0.006 & -0.001 & & 0.006 \\
\hline POL $\times$ old 70 & -0.020 & $* * *$ & 0.006 & -0.001 & & 0.006 & 0.002 & & 0.006 \\
\hline VPC_overall & 0.121 & & & 0.048 & & & 0.058 & & \\
\hline VPC_level 2 & 0.572 & & & 0.419 & & & 0.453 & & \\
\hline
\end{tabular}


Table 9: Two-Level probit regression flexicurity: the impact of flexicurity by age

\begin{tabular}{lcccccccccccc}
\hline & \multicolumn{3}{c}{ ALL } & \multicolumn{3}{c}{ 25-34 } & \multicolumn{3}{c}{ 35-44 } & \multicolumn{2}{c}{$45-54$} \\
\hline & Coef. & & St.Err. & Coef. & & St.Err. & Coef. & & St.Err. & Coef. & St.Err. \\
FLEX & -0.248 & $* *$ & 0.118 & -0.197 & & 0.139 & -0.131 & & 0.094 & -0.057 & 0.072 \\
SEC & -0.209 & $*$ & 0.116 & -0.168 & $*$ & 0.098 & -0.132 & & 0.097 & -0.044 & 0.07 \\
FLEX x SEC & 0.118 & $*$ & 0.061 & 0.095 & $*$ & 0.05 & 0.084 & $*$ & 0.044 & 0.029 & 0.033 \\
FLEX x child06 & -0.057 & $* * *$ & 0.003 & -0.056 & $* * *$ & 0.004 & -0.069 & $* * *$ & 0.004 & -0.044 & 0.011 \\
SEC x child06 & -0.022 & $* * *$ & 0.004 & 0.021 & $* * *$ & 0.006 & -0.067 & $* * *$ & 0.007 & -0.022 & 0.019 \\
FLEX x SEC x child06 & 0.025 & $* * *$ & 0.002 & 0.019 & $* * *$ & 0.003 & 0.038 & $* * *$ & 0.003 & 0.016 & 0.009 \\
FLEX x old70 & -0.022 & $* * *$ & 0.005 & -0.027 & $* *$ & 0.011 & -0.033 & $* * *$ & 0.009 & -0.01 & 0.008 \\
SEC x old70 & -0.031 & $* * *$ & 0.008 & -0.042 & $* * *$ & 0.016 & -0.036 & $* * *$ & 0.013 & -0.017 & 0.012 \\
FLEX x SEC x old70 & 0.006 & & 0.005 & 0.022 & $* *$ & 0.01 & 0.01 & & 0.008 & -0.007 & 0.007 \\
\hline VPC_overall & 0.224 & & & 0.257 & & & 0.308 & & & 0.333 & \\
VPC_level 2 & 0.264 & & & 0.287 & & & 0.385 & & & 0.589 & \\
\hline
\end{tabular}

Table 10: Two-Level probit regression flexicurity: the impact of flexicirity by education

\begin{tabular}{lccccccccc}
\hline & \multicolumn{2}{c}{ ISCED 0-2 } & \multicolumn{2}{c}{ ISCED 3-5 } & \multicolumn{2}{c}{ ISCED 5-7 } \\
\hline & Coef. & & St.Err. & Coef. & & St.Err. & Coef. & St.Err. \\
& & & & & & & & \\
FLEX & -0.136 & & 0.149 & -0.002 & & 0.064 & -0.014 & 0.046 \\
SEC & -0.242 & $*$ & 0.149 & 0.022 & & 0.063 & -0.007 & 0.049 \\
FLEX x SEC & 0.133 & $* * *$ & 0.054 & 0.026 & & 0.032 & 0.022 & 0.025 \\
FLEX x child06 & -0.067 & $* * *$ & 0.005 & -0.084 & $* * *$ & 0.005 & -0.052 & $* * *$ & 0.004 \\
SEC x child06 & -0.010 & & 0.008 & -0.048 & $* * *$ & 0.006 & 0.014 & $* *$ & 0.006 \\
FLEX x SEC x child06 & 0.019 & $* * *$ & 0.004 & 0.038 & $* * *$ & 0.003 & 0.006 & $*$ & 0.003 \\
FLEX x old70 & -0.002 & & 0.009 & -0.048 & $* * *$ & 0.010 & -0.013 & 0.009 \\
SEC x old70 & -0.013 & & 0.013 & -0.078 & $* * *$ & 0.014 & -0.009 & 0.014 \\
FLEX x SEC x old70 & 0.017 & $* *$ & 0.008 & 0.035 & $* * *$ & 0.008 & 0.005 & 0.009 \\
\hline VPC_overall & 0.365 & & & 0.211 & & & 0.211 & & \\
VPC_level 2 & 0.418 & & & 0.322 & & & 0.323 & \\
\hline
\end{tabular}


Table 11: INST and POL contribution to female participation

\begin{tabular}{|c|c|c|c|c|}
\hline & \multicolumn{4}{|c|}{ EU15 } \\
\hline & $\begin{array}{c}\Delta \\
\text { activity } \\
\text { rate }\end{array}$ & $\begin{array}{l}\text { predicted } \\
\text { by INST } \\
\text { and POL c }\end{array}$ & $\begin{array}{l}\text { predicted } \\
\text { by other } \\
\text { observables }\end{array}$ & $\begin{array}{c}\text { INST and } \\
\text { POL } \\
\text { contribution } \\
(\%)\end{array}$ \\
\hline 1995 & 0.0053 & 0.0009 & 0.0007 & 0.170 \\
\hline 1996 & 0.0165 & 0.0005 & 0.0087 & 0.030 \\
\hline 1997 & 0.0234 & 0.0011 & 0.0183 & 0.047 \\
\hline 1998 & 0.0318 & 0.0025 & 0.0123 & 0.079 \\
\hline 1999 & 0.0439 & 0.0027 & 0.0130 & 0.062 \\
\hline 2000 & 0.0515 & 0.0037 & 0.0097 & 0.072 \\
\hline 2004 & 0.0813 & 0.0021 & 0.0558 & 0.026 \\
\hline 2005 & 0.0888 & 0.0046 & 0.0605 & 0.052 \\
\hline 2006 & 0.0970 & 0.0055 & 0.0626 & 0.057 \\
\hline 2007 & 0.1023 & 0.0070 & 0.0640 & 0.068 \\
\hline 2008 & 0.1073 & 0.0075 & 0.0614 & 0.070 \\
\hline 2009 & 0.1130 & 0.0026 & 0.0557 & 0.023 \\
\hline me & & & & 0.063 \\
\hline
\end{tabular}


Table 12: INST and POL contribution to female participation by welfare regime

\begin{tabular}{|c|c|c|c|c|c|c|c|c|}
\hline & $\begin{array}{c}\Delta \\
\text { activity } \\
\text { rate }\end{array}$ & $\begin{array}{l}\text { predicted } \\
\text { by INST } \\
\text { and POL } \\
\end{array}$ & $\begin{array}{c}\text { predicted } \\
\text { by other } \\
\text { observables }\end{array}$ & $\begin{array}{c}\text { INST and } \\
\text { POL } \\
\text { contribution } \\
(\%) \\
\end{array}$ & $\begin{array}{c}\Delta \\
\text { activity } \\
\text { rate }\end{array}$ & $\begin{array}{l}\text { predicted } \\
\text { by INST } \\
\text { and POL }\end{array}$ & $\begin{array}{c}\text { predicted } \\
\text { by other } \\
\text { observables }\end{array}$ & $\begin{array}{c}\text { INST and } \\
\text { POL } \\
\text { contribution } \\
(\%)\end{array}$ \\
\hline & \multicolumn{4}{|c|}{ Continental } & \multicolumn{4}{|c|}{ Social Democratic } \\
\hline 1995 & 0.0059 & 0.0008 & -0.0036 & 0.136 & -0.001 & 0.0007 & -0.0064 & -0.700 \\
\hline 1996 & 0.0186 & 0.0001 & -0.0029 & 0.005 & -0.001 & -0.0002 & -0.0198 & 0.200 \\
\hline 1997 & 0.0307 & 0.0007 & -0.0011 & 0.023 & -0.0083 & 0.0014 & -0.0192 & -0.169 \\
\hline 1998 & 0.0407 & 0.0032 & -0.025 & 0.079 & -0.0067 & 0.0021 & -0.0184 & -0.313 \\
\hline 1999 & 0.0566 & 0.004 & -0.0263 & 0.071 & -0.0007 & 0.0002 & -0.0175 & -0.271 \\
\hline 2000 & 0.0651 & 0.0051 & -0.031 & 0.078 & -0.0003 & 0.00017 & -0.015 & -0.567 \\
\hline 2004 & 0.0996 & -0.0003 & 0.0279 & -0.003 & 0.0003 & 0.00023 & 0.0016 & 0.767 \\
\hline 2005 & 0.109 & 0.0058 & 0.0429 & 0.053 & 0.0053 & 0.0045 & 0.0002 & 0.849 \\
\hline 2006 & 0.1181 & 0.0064 & 0.0439 & 0.054 & 0.0083 & 0.0053 & 0.0009 & 0.639 \\
\hline 2007 & 0.126 & 0.0074 & 0.0454 & 0.059 & 0.0117 & 0.0075 & -0.0008 & 0.641 \\
\hline 2008 & 0.1281 & 0.0098 & 0.0413 & 0.077 & 0.018 & 0.0079 & -0.0046 & 0.439 \\
\hline 2009 & 0.1357 & 0.0027 & 0.0319 & 0.020 & 0.016 & 0.0031 & -0.0091 & 0.194 \\
\hline \multirow[t]{2}{*}{ mean } & & & & 0.054 & & & & 0.142 \\
\hline & \multicolumn{4}{|c|}{ Liberal } & \multicolumn{4}{|c|}{ Southern } \\
\hline 1995 & 0.002 & -0.0002 & 0.0017 & -0.100 & 0.0097 & 0.0009 & 0.0031 & 0.093 \\
\hline 1996 & 0.007 & 0.0002 & 0.0038 & 0.029 & 0.0283 & 0.0014 & 0.004 & 0.049 \\
\hline 1997 & 0.011 & 0.0003 & 0.0059 & 0.027 & 0.0375 & 0.002 & 0.0057 & 0.053 \\
\hline 1998 & 0.013 & 0.0006 & 0.0534 & 0.046 & 0.0498 & 0.0025 & 0.0082 & 0.050 \\
\hline 1999 & 0.021 & 0.0009 & 0.0585 & 0.043 & 0.0607 & 0.0019 & 0.01 & 0.031 \\
\hline 2000 & 0.023 & 0.0022 & 0.0395 & 0.096 & 0.0735 & 0.0018 & 0.0125 & 0.024 \\
\hline 2004 & & & & & 0.1235 & 0.0013 & 0.0499 & 0.011 \\
\hline 2005 & 0.034 & 0.004 & 0.0739 & 0.118 & 0.1298 & 0.002 & 0.0514 & 0.015 \\
\hline 2006 & 0.037 & 0.0038 & 0.0708 & 0.103 & 0.1415 & 0.0032 & 0.0547 & 0.023 \\
\hline 2007 & 0.037 & 0.004 & 0.0774 & 0.108 & 0.145 & 0.0049 & 0.0563 & 0.034 \\
\hline 2008 & 0.043 & 0.0035 & 0.0764 & 0.081 & 0.1537 & 0.0038 & 0.0552 & 0.025 \\
\hline 2009 & & & & & 0.1622 & -0.0006 & 0.0562 & -0.004 \\
\hline mean & & & & 0.055 & & & & 0.034 \\
\hline
\end{tabular}


Table 13: INST and POL contribution to female participation by age groups

\begin{tabular}{|c|c|c|c|c|c|c|c|c|c|c|c|c|}
\hline \multicolumn{5}{|c|}{ 25-34 } & \multicolumn{4}{|c|}{$35-44$} & \multicolumn{4}{|c|}{$45-54$} \\
\hline & $\begin{array}{l}\Delta \\
\text { activity } \\
\text { rate } \\
\end{array}$ & $\begin{array}{l}\text { predicted } \\
\text { by INST } \\
\text { and POL }\end{array}$ & $\begin{array}{l}\text { predicted } \\
\text { by other } \\
\text { observables }\end{array}$ & $\begin{array}{c}\text { INST and } \\
\text { POL } \\
\text { contribution } \\
(\%) \\
\end{array}$ & $\begin{array}{c}\Delta \\
\text { activity } \\
\text { rate }\end{array}$ & $\begin{array}{l}\text { predicted } \\
\text { by INST } \\
\text { and POL }\end{array}$ & $\begin{array}{c}\text { predicted } \\
\text { by other } \\
\text { observables } \\
\end{array}$ & $\begin{array}{c}\text { INST and } \\
\text { POL } \\
\text { contribution } \\
(\%) \\
\end{array}$ & $\begin{array}{c}\Delta \\
\text { activity } \\
\text { rate }\end{array}$ & $\begin{array}{l}\text { predicted } \\
\text { by INST } \\
\text { and POL }\end{array}$ & $\begin{array}{c}\text { predicted } \\
\text { by other } \\
\text { observables }\end{array}$ & $\begin{array}{c}\text { INST and } \\
\text { POL } \\
\text { contribution } \\
(\%) \\
\end{array}$ \\
\hline 1995 & 0.0160 & 0.0073 & -0.0028 & 0.456 & 0.0346 & 0.0003 & -0.0030 & 0.009 & 0.0556 & -0.0031 & 0.0089 & -0.056 \\
\hline 1996 & 0.0290 & 0.0032 & -0.0022 & 0.110 & 0.0473 & 0.0013 & 0.0026 & 0.027 & 0.0609 & 0.0012 & 0.0276 & 0.020 \\
\hline 1997 & 0.0342 & 0.0043 & -0.0074 & 0.126 & 0.0549 & 0.0022 & 0.0098 & 0.040 & 0.0728 & 0.0024 & 0.0535 & 0.033 \\
\hline 1998 & 0.0380 & 0.0088 & -0.0172 & 0.232 & 0.0580 & 0.0045 & 0.0003 & 0.078 & 0.0876 & 0.0007 & 0.0536 & 0.008 \\
\hline 1999 & 0.0509 & 0.0108 & -0.0209 & 0.212 & 0.0713 & 0.0048 & -0.0021 & 0.067 & 0.1049 & 0.0004 & 0.0629 & 0.004 \\
\hline 2000 & 0.0598 & 0.0191 & -0.0331 & 0.319 & 0.0796 & 0.0045 & -0.0063 & 0.057 & 0.1121 & -0.0040 & 0.0675 & -0.036 \\
\hline 2004 & 0.0741 & 0.0159 & 0.0314 & 0.215 & 0.1044 & 0.0006 & 0.0523 & 0.006 & 0.1614 & -0.0031 & 0.1078 & -0.019 \\
\hline 2005 & 0.0769 & 0.0195 & 0.0019 & 0.254 & 0.1110 & 0.0068 & 0.0509 & 0.061 & 0.1772 & -0.0015 & 0.1415 & -0.008 \\
\hline 2006 & 0.0842 & 0.0229 & -0.0041 & 0.272 & 0.1194 & 0.0077 & 0.0518 & 0.064 & 0.1871 & -0.0033 & 0.1536 & -0.018 \\
\hline 2007 & 0.0856 & 0.0289 & -0.0098 & 0.338 & 0.1257 & 0.0094 & 0.0523 & 0.075 & 0.1962 & -0.0060 & 0.1638 & -0.031 \\
\hline 2008 & 0.0887 & 0.0291 & -0.0176 & 0.328 & 0.1285 & 0.0104 & 0.0493 & 0.081 & 0.2061 & -0.0057 & 0.1657 & -0.028 \\
\hline 2009 & 0.0949 & 0.0087 & -0.0207 & 0.092 & 0.1359 & 0.0038 & 0.0423 & 0.028 & 0.2107 & 0.0005 & 0.1598 & 0.002 \\
\hline
\end{tabular}


Table 14: INST and POL contribution to female participation by education groups

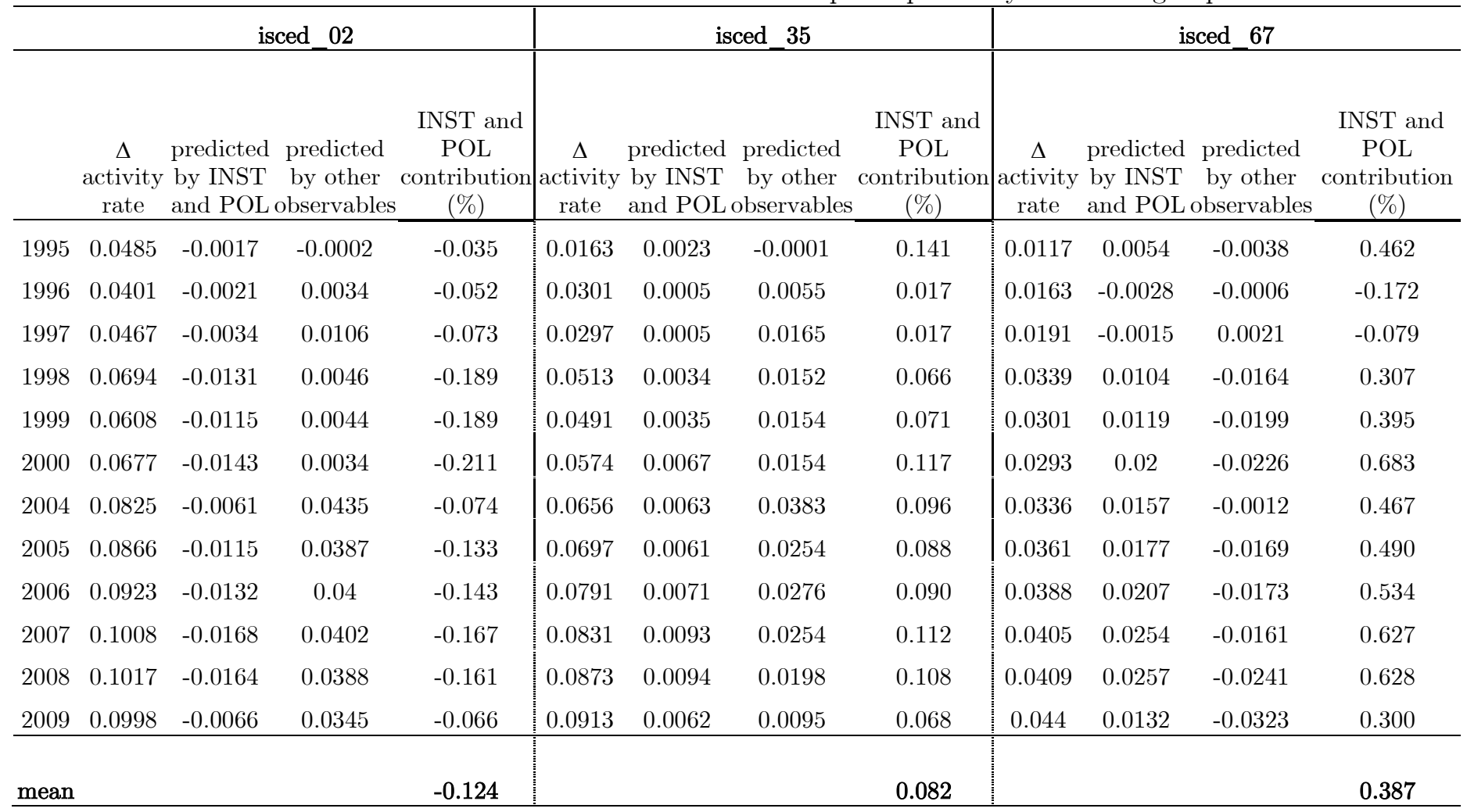


Figure 1. Macro data trends in Europe: Activity rate by gender, 1994-2009

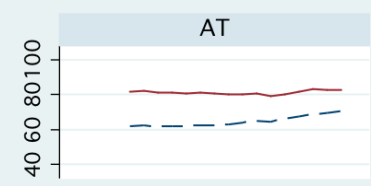

ES

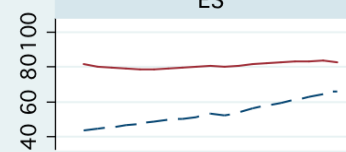

GR

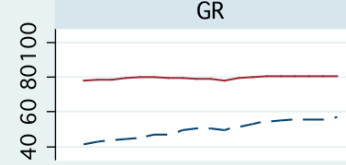

NL

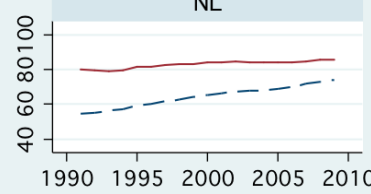

PT

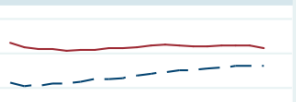

- - - - -

IE
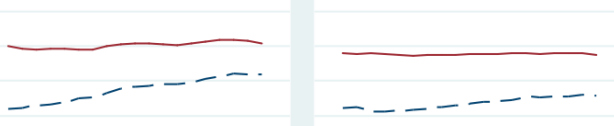

SE

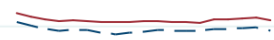

$-\cdots-\cdots$

DK

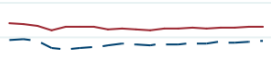

FR

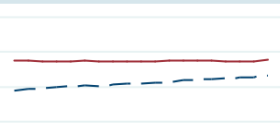

LU

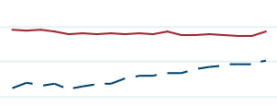

UK

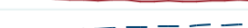

$----\cdots$

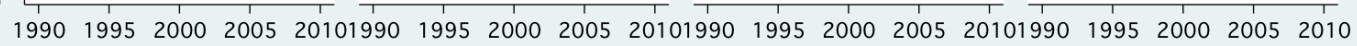

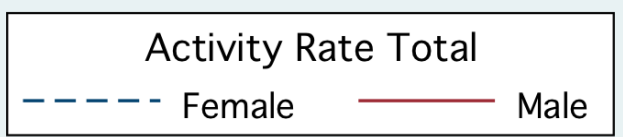

Graphs by Country

Source: OECD Labour Market Statistics retrieved from http://stats.oecd.org/.

Figure 2. Macro data trends in Europe: Unemployment rate by gender, 1994-2009

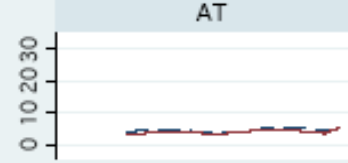

ES

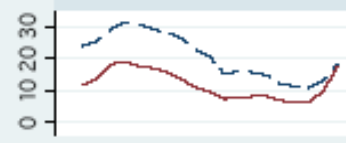

GR

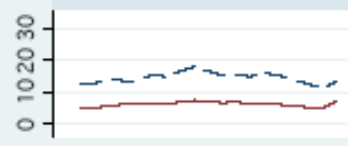

NL

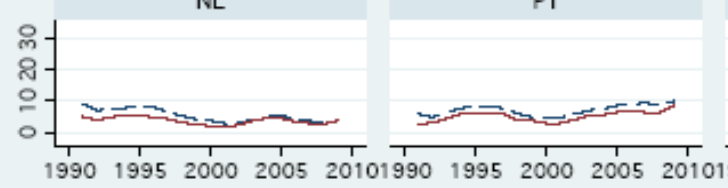

EU

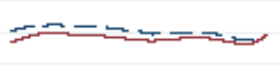

IE

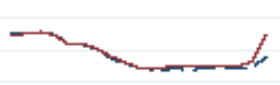

PT

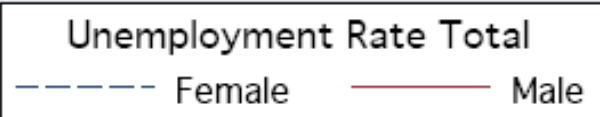

Graphs by Country

Source: OECD Labour Market Statistics retrieved from http:/ /stats.oecd.org/.
DK

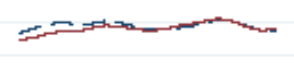

FI

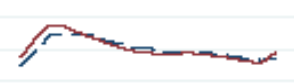

IT

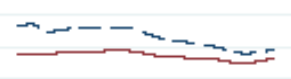

SE
UK

FR

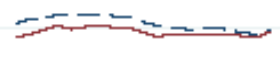

LU

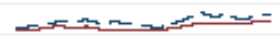

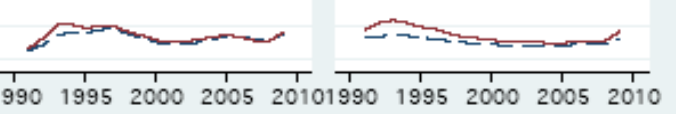

Male

STقTق币 
Figure 3. Micro-based gender gap index in activity rates, 1994-2009
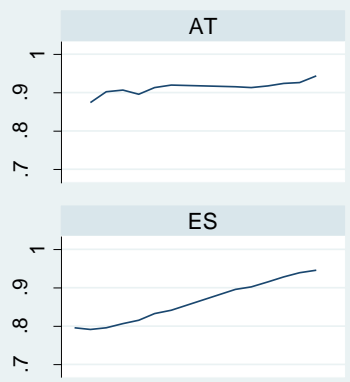

IE

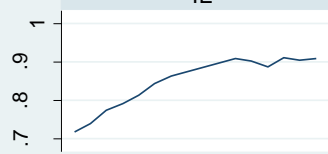

PT

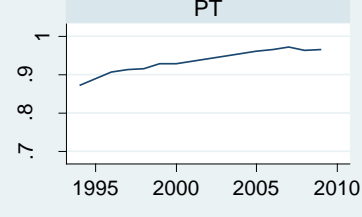

Graphs by country1
BE

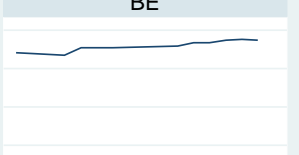

$\mathrm{FI}$

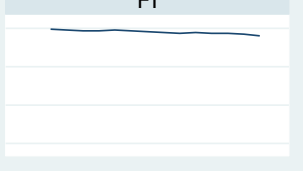

IT

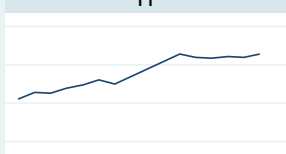

SE

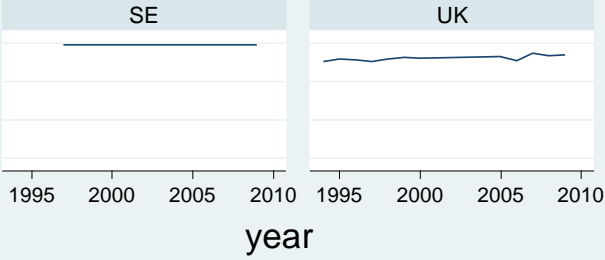

DE

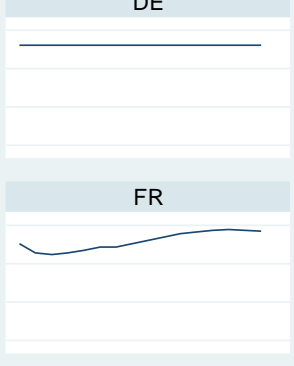

LU

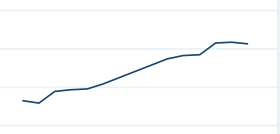

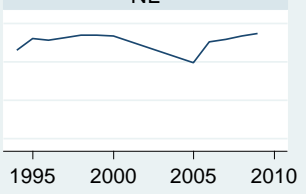

GR

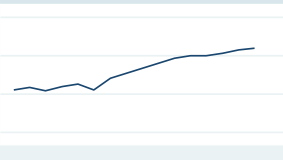

NL

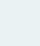

Source: Own elaborations from ECHP and EUSILC databases.

Figure 4. Micro-based gender gap index in unemployment rates, 1994-2009

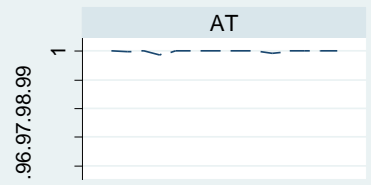

ES
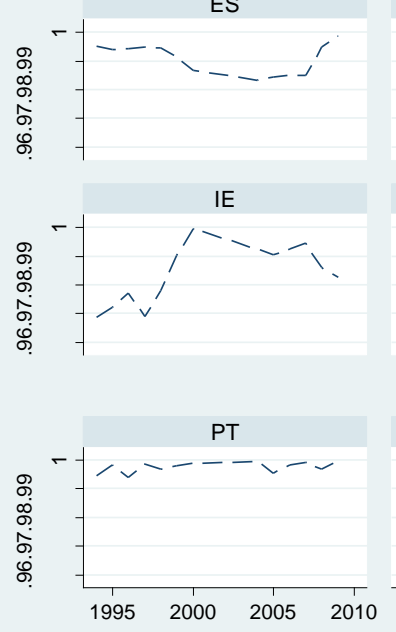

Graphs by country1

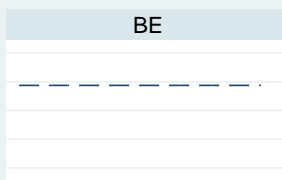

$\mathrm{FI}$

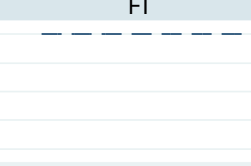

IT

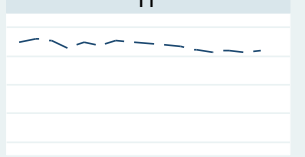

UK

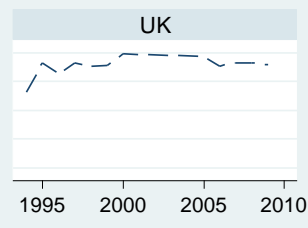

year
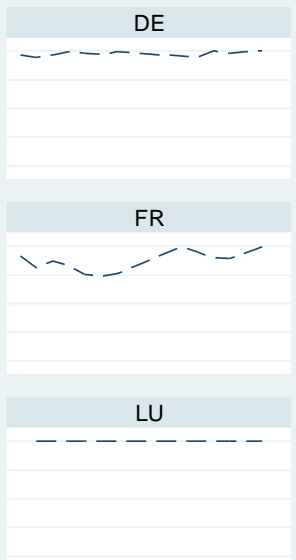

FR
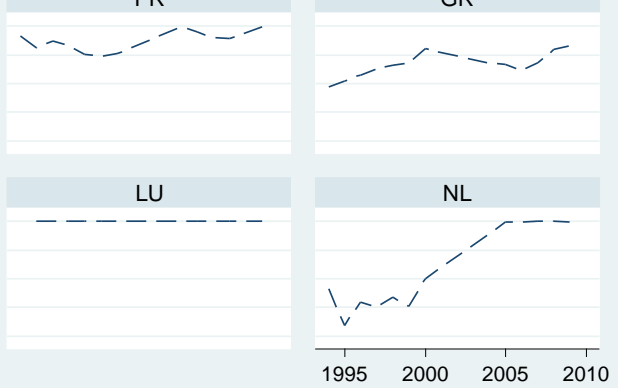

Source: Own elaborations from ECHP and EUSILC databases. 
Figure 5: The flexicurity dimensions

\section{4-2009}

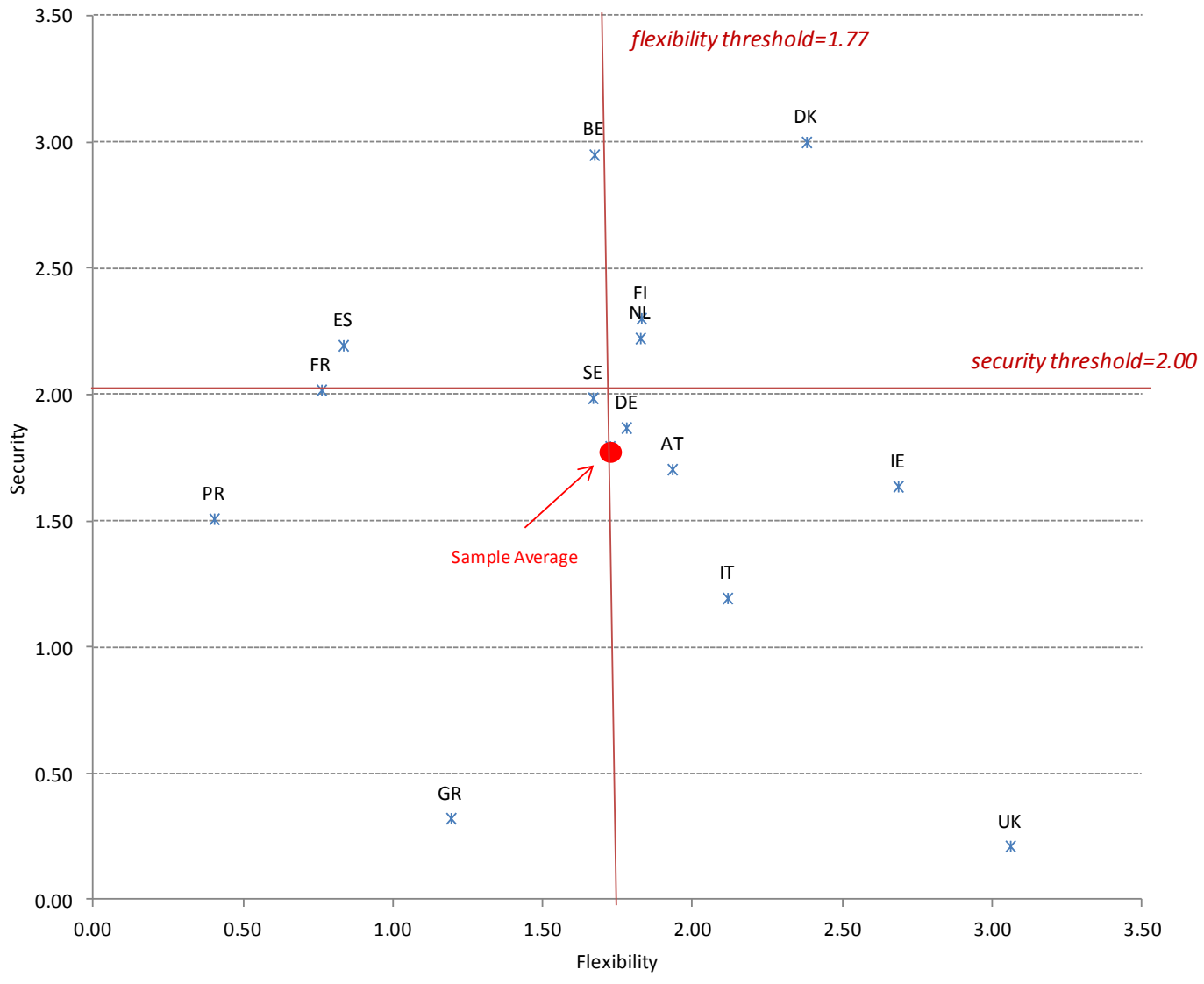

Source: Own elaborations from OECD institutions and SOCX databases 